\title{
An analysis of informal work: The case of sub-Saharan waste pickers in the city of Barcelona
}

\author{
Julián Porras Bulla (iD, Víctor Climent Sanjuán (iD) \\ Universitat de Barcelona (Spain) \\ japbulla@botmail.com,vcliment@ub.edu
}

\section{Abstract}

Purpose: To analyse the framework within which the informal labour market operates and the social implications of this market by conducting a case study of sub-Saharan scrap metal waste pickers chatarreros - in the city of Barcelona.

Design/methodology: The study compares and contrast theoretical findings drawn from the literature about informal work and the social and living conditions of Barcelona's chatarreros. Our primary data are collected from twelve interviews (ten with scrap metal waste pickers and two with neighbourhood leaders) and from ethnographic fieldwork conducted between February and August 2013.

Contributions and results: Barcelona, in common with many other cities in the northern hemisphere, has experienced a growth in informal work directly linked to the tourism sector, the city's main economic activity. This growth was especially marked in the Great Recession (2008-2015). Traditionally, informal workers have been systematically ignored, recognition being saved solely for those legally or formally employed. But the major economic changes of the last 20 years have led to the transformation of labour markets and to the segmentation and precarisation of work, and with it the growth of the informal sector. Here, we analyse three elements that are critical for understanding this sector: recognition of work, its capitalisation and the relation between the individual and work.

Limitations: This study, for reasons of space, limits itself to an examination of one group of informal workers in Barcelona, namely the chatarreros; however, there are many other groups that are worthy of study, including, the city's street vendors, and street artists: buskers, living statues, caricaturists, etc

Originality/value: The study serves to fill the gap in knowledge regarding the reality of informal work and its social consequences. Specifically, it facilitates understanding of the theoretical concept of informality, illustrating, by means of a case study of informal recyclers or scrap metal waste pickers, the economic and social condition of informal immigrant workers characterised by poverty, discrimination, disembeddedness and subsistence.

Keywords: Informal work, Poverty, Working conditions, Immigration, Discrimination

Jel Codes: J46, I32, J81, F22, J71 


\section{To cite this article:}

Porras Bulla, J., \& Climent Sanjuán, V. (2018). An analysis of informal work: The case of Sub-Saharan scrap metal waste pickers in the city of Barcelona. Intangible Capital, 14(4), 536-568. https://doi.org/10.3926/ic.1335

\section{Introduction}

The economic crisis that broke out in 2008 has accelerated the deterioration of the world of work in the 20thcentury. Greater labour flexibility, the increasing offshoring of jobs, the growing precariousness faced by workers and rising rates of unemployment are traits that have come to characterise the current job market, which is undergoing a transformation attributable to multiple causes: technology change (Castells, 2000), the shift from solid to liquid modernity (Bauman, 2004), and changes of a more structural nature related to modes of accumulation (Wallerstein, 2013).

Enrique de la Garza (2001) describes it as a crisis made up of various parallel processes: technology development, a reduction in industrial employment, an increase in service sector employment, the displacement of production to places where the linkages between work and capital are far from easyand changes in the dominant theories of economic analysis. And the main consequence is the loss of the centrality of work in the post-industrial society and the emergence of two conflicting arguments: increasingly there are fewer jobs in our societies (Rifkin, 1996) and increasingly what jobs there are becoming more hidden (Castillo, 1998; Castillo \& de la Garza Toledo, 2000; Pahl, 1991).

To a large extent, the explanation for this transformation lies in the growing distance between the world of work and the economy (Polanyi, 1989), a distance that appears to be based on the fact that most of the capital is produced in the financial sector, but with no causal ties with the world of work. For example, global wealth in 2015, according to estimates published in the Global Wealth Report (Credit Suisse, 2015), stood at around 250 billion dollars and about $50 \%$ of this was concentrated in the financial sector.

However, if we look beyond these figures, we see that the world of work is a restricted space where only legal, quantifiable activities actually count, while the jobs performed by caregivers, immigrants, the unemployed, students, pensioners, etc. are invisible. The labour market is, as a rule, a space composed of a broad range of occupations and activities carried out within the heart of society. But, at the same time, it is an exclusive space where many activities, alien to the dominant paradigm, cannot find representation (Pahl, 1991). Moreover, the dominant idea about work is not constant but rather it has evolved over the last two centuries and its impact has differed different depending on the specific territory or moment in history under examination (Wallerstein, 1988).

Yet, today, it is becoming increasingly difficult to define the shape taken by the dominant model of work, given that growing labour flexibility and the changes produced in capital-labour relations have led to a breakdown between the classical industrial wage-earner model and an emerging model closely linked to economic globalisation, where elements such as urban dynamics, migration and unemployment make up transversal movements in big cities (Portes \& Sassen-Koob, 1987).

One of the determining factors of the crisis affecting the world of work is the growing importance of informal work in big cities. And although disaggregated data obtained by direct methods are scarce, Schneider, using a multiple indicators multiple causes (MIMIC) model, calculates that approximately $18.5 \%$ of the Spanish economy is submerged (2018), to which we need to realise that informal work is becoming increasingly more frequent and more complex. In fact, in Barcelona, as in any other big city, one need only walk its streets to be aware of the pervasive presence of informal work: so-called waste pickers or informal recyclers of scrap metal (henceforth, chatarreros), street vendors (including those selling cans of beer and balloons), cycle rickshaw drivers, buskers, living statues, caricaturists, dancers, knife sharpeners, flyer distributors, etc. 
This study seeks to account for this phenomenon by examining the case of sub-Saharan chatarreros in Barcelona, an example of informal work that is found in most of the world's major cities (Fernández, Pena Pan \& ReyMazón, 2014). The fieldwork was conducted in 2013, coinciding with the eviction of a factory building/warehouse occupied on Puigcerdà Street in the barrio of Poblenou (a city district undergoing a high rate of gentrification). This site was where the city's sub-Saharan chatarreros tended to congregate and, indeed, many people of different nationalities - although the majority were from Senegal - lived in this former factory building.

The factory in Puigcerdà Street was made up of a number of warehouses, each with its main entrance opening out onto a central street. Each warehouse was assigned a given function within a specific division of labour as follows: separation of metals, the collection of re-usable goods, and services, including a bar, hairdresser's and café. And while, in most of the warehouses, the productive activities centred on the repair and storage of reusable materials or objects, each warehouse could be said to operate as a productive unit, with multiple types of ownership, solidarity, cooperation and internal hierarchy.

Following the serving of an eviction order in July 2013, the chatarreros were displaced to other enclaves, resulting in the disarticulation of the community and the weakening of their political demands. This study was conducted three months before and two months after the eviction. It employs a qualitative methodology based on the triangulation of information (Denzin \& Lincoln, 2012) from ethnographic observation, an analysis of the news media and twelve interviews (ten with chatarreros and two with neighbourhood leaders). The bulk of the information, discourse and data contained in this article was generated by three research techniques: participant observation, semi-structured interviews and news media analyses. The semi-structured interview took three levels of approach in an effort to study the work of the chatarreros in its broadest sense (Miguélez \& Torns, 1998): the first referring to time (productive-reproductive-free time and life trajectory); the second referring to levels of socialisation; and the third to structures of meaning. Ethnographic observation was carried out between February and August 2013 at meetings, demonstrations, and at events both before and after the eviction of the Puigcerdà factory (July 2013). The news media analysis was based on a matrix that corresponds to the periods of participant observation, and was built from different pre-identified journalistic themes (namely, the police, the public space, politics, collective groups, trade and opposition associations). The selection of articles was governed by two factors: one transversal, which cuts across the whole timeline, and another that focuses on moments of significant content production (such as the demonstrations organised prior to eviction, the eviction itself and the subsequent protests). The sources of news media selected (namely, El País, La Vanguardia, El Periódico, El Diario and La Directa) reflect a broad range of political opinion and a broad geography and together provide a good understanding of the social construction of the activities and their executors. Finally, the analysis of these three sources of information is based on the following matrix:

1. Time: basic characterisation of time: productive-reproductive-free time and life trajectory.

2. Socialisation: construction of the subject, construction of "us", construction of the other.

3. Meaning: work, capital; recognition, organisation, regularisation.

\section{The new social context of the labour market}

Clearly, the paradigm shift undergone by the labour factor is closely related to the new economic reality typified by globalisation and the subsequent consequences of the great economic and financial crisis of 2008-2015. The factors that have had the greatest impact on the deterioration of the labour market have been the increase in unemployment, the consolidation of its structural precariousness and the increased risk of poverty of broad swathes of the working classes, above all in the countries of southern Europe. Until the 1990s, being in paid employment was a critical factor, a guarantee of social integration and economic stability, while traditional profiles of poverty were typically associated with old age, immigration, unemployment or submerged work. However, from the nineties onwards, the risk of falling into poverty began to affect a growing number of social groups that had not exited the labour market (or which were constantly entering and leaving it) and who were 
exposed to the growing precariousness of their working conditions, converting them into the de facto 'nouveau poor' (Climent, 2015).

Although the economic conditions recorded between 2008 and 2015 had an enormous influence on the evolution of the labour market, we cannot ignore the fact that in recent decades there have been economic and social changes that also help account for the intense precariousness of the labour market and the weakening of the classical paradigm of the work factor. New production processes, technology changes and the growing flexibility of the job market, especially in Spain, have had a strong impact on labour relations. The consequences have been the exacerbation of social inequality related to an increasingly segmented labour market and where the most vulnerable social groups find themselves trapped in the vicious circle of taking low-skilled jobs or being unemployed, which, sooner rather than later, abandons them to poverty and social exclusion. The result is a growing segmentation of the labour market in which three broad groups coexist: a first group of "core" workers, formerly the majority, with good salaries and working conditions; a second group, increasingin number all the time, of wage-earners and (usually false) self-employed workers whose link with the labour market is increasingly being weakened; and a third group, also on the increase, made up of workers who act outside the classical paradigm and who constitute what we call the submerged or informal sector.

Likewise, the current economic framework is generating higher levels of poverty, not only because of unemployment, but also because of the progressive deterioration of working conditions. In this sense, the cracks appearing in the welfare state and the growth of poverty (Beck, 2002; Esping-Andersen, 2000) in recent years are affecting virtually all areas of our society. The structural 'precarisation' of working conditions, the devaluation of wages and the dissolution of the link with the world of work have led to an inevitable expansion of the informal economy and increasing levels of social exclusion. Against this backdrop, the severity of the crisis and the strictness of the austerity policies adopted have merely served to place the labour market under greater pressure, so that the percentage of workers exposed to a future scenario of 'informal' work and poverty is growing. And although it is quite clear that there are groups of individuals who are much more vulnerable to poverty (immigrants, the long-term unemployed and low-skilled wage earners), it is also true that social vulnerability is spreading rapidly towards new socio-economic areas, historically considered the preserve of the middle classes, where new risk profiles of poverty are emerging. That is, people who have lost their jobs, households that have seen a substantial reduction in their income and families with growing difficulties to pay off their debts. In other words, the gradual disappearance of quality employment - that is, what has hitherto been considered as underpinning the concept of social citizenship (Rifkin, 1996, Beck, 2000) - is irreversibly undermining the great social pact entered into after the Second World War and the classical paradigm of work in the post-industrial capitalist society.

\subsection{On other forms of work and other types of worker}

Contrary to what might initially be thought, the meaning of the concept of work is not especially transparent. Yet, it is a central notion within the various social disciplines and, moreover, accounts for a not insignificant part of our lives. Indeed, it is a concept that presents various difficulties when social scientists seek to reach a consensus regarding its meaning (McGovern, 2013), being the object of theoretical reviews (Noguera Ferrer, 1998) and of numerous economic, sociological and philosophical studies (Arendt, 2009). And while there are many arguments that interpret work as a defining element of the prevailing paradigm, the marked economism of the social sciences hinders the analysis of "other forms of work". In fact, the discipline of economics has constructed a discourse that considers economic elements as structural and the market as the regulatory mechanism par excellence (Misas, 1993). For decades, thinking in economics has forged a dominant model of work based on one very simple idea: there is nothing outside the market other than poverty. In this way, a clear correlation has been established between economic sufficiency and access to the job market. And even Marxism, which admits the existence of other forms of work, elevates waged work to an ideological and political category, recognising it as a social group to represent (Mingione, 1994). 
The main theoretical reference for the analysis of "other jobs" and "other workers" originates from studies of informality and is the theoretical and political apparatus most widely employed by neoliberalism to understand, explain and offer solutions to the phenomenon of "other jobs" (de la Garza Toledo, 2011).

The concept of informality, developed out of the work of Keith Hart (1973) on the job market of Ghana and the ILO 'employment mission' to Kenya in 1974. It emerged specifically from the need to explain the characteristics of a labour structure that failed to coincide with the traditional models studied by economists of the day. And although these early authors did not associate informal activities with negative circumstances, informality has come to be a concept that is generally related to the poverty-work binomial (Chen, 2012).

The concept of informal work cannot be explained by a single causal theory; it is highly heterogeneous, and can be a negative burden on the worker, since it highlights specific phenomena not addressed by the theoretical lines of thought based more fully on the dominant model of work.

One of the characteristics of informal work is that it is a fundamentally urban phenomenon (Sassen, 1988), while it has become a key concept in the terminology of international organisations who use it in close relation with both living and working conditions (ILO, World Bank, IMF, UN). Likewise, informal work is an indicator of inequality, in the sense that it can serve to support the reproduction of other economic activities, as is the case of women's work in the home. Yet, at the same time, it is a functional model: first, because it absorbs labour force surpluses when there is not enough employment and the structural conditions do not favour good working conditions and, second, because it is a source of cheap labour supply. And it can achieve this in a direct manner, by way of all those activities that are devoid of the characteristics of waged work, but which have a similar mission (hospitality sector, construction, etc.). Or it can do so indirectly, by way of all those tasks that can be associated with (true or false) self-employment, such as chatarreros, street vendors, domestic workers, etc. (Chant \& Pedwell, 2008).

There exists, moreover, a broad range of interpretations of the concept of informality. Some emphasise the analysis of the informal economy as if it had a different structure from that of the modes of production of the formal economy, while others focus their analysis on informality in terms of those firms and workers that fail to comply with the necessary legal requirements. Rolando Lazarte (2000) revisits the description provided by Dagmar Raczynzki regarding the three approaches to the informal sector. The first refers to a productive apparatus that can be defined as a group of small production units, characterised by low technology and a lack of economic rationality and where personal and family relationships are given greater importance than labour relations. The second refers to the type of occupation in which the main characteristics of forming part of the informal labour market are defined (easy access, low educational levels and low income levels) and which affects the population that cannot access formal jobs. And in the third, we find those low-income economic activities that, generally, can only survive as informal jobs. In contrast, for Cimolli, Primi and Pugno (2006, pp. 91), the informal sector is the response to excessive State regulation and bureaucracy in the exercising of certain productive activities and, in a similar vein, de Soto, Ghersi and Ghibellini (1987) argues that the best way to eliminate informality is to reduce regulatory barriers.

Thus, informality can be interpreted from different angles (Lazarte, 2000). For the ILO (2002), it is a model of low capital investment, low access barriers and low use of knowledge and technology. From neoliberal perspectives or similar, informality is a phenomenon created by the State, a product of the regulation of labour activities and relations that hinder the natural functioning of the market (de Soto et al., 1987). Alternatively, form a structural perspective of the informal sector, it is, above all, a basically low-cost labour model (Portes \& Zhou, 1996; Cimolli et al., 2006).

Undoubtedly, informality has played a fundamental role in interpreting, and seeking solutions to, all those jobs that do not fall within the institutional framework. However, we need to bear in mind at least three axes of analysis when discussing informality: the academic, the political and the cyclical. A consideration of the various perspectives on informality can lead to a broad discussion of the variables that determine what exactly constitutes formal or informal work (Shapland \& Heyes, 2017). Similarly, informality acts as a regulator of labour markets that have an inadequate format (de la Garza Toledo, 2011) and whose repercussions are becoming 
increasingly global (Hilbrandt \& Richter, 2015; Williams, 2013). And finally, debates about the cyclical function of the concept lead us to consider its usefulness in periods of economic expansion and in times of crisis (Siqueira, 2016). An example of just this is currently being played out in the big cities of the northern hemisphere, where the concern for growing disarticulated populations has been adopted by groups that organise themselves around the rights of citizens, work and institutional recognition (Espinosa, 2017; Pradel-Miquel, 2016; Sariento, Tilly, de la Garza Toledo \& Gayosso Ramírez, 2016). However, where there has been the most marked increase in academic research of informal work - outside, that is, of the classical literature associated with "underdevelopment" (Pfau-Effinger, 2017) and criminology (Edelbache, Kratcoski \& Dobovsek, 2016; Ponsaers, Shapland \& Williams, 2008) - is in case studies of big cities in "developed" countries, focusing, for example, on street vendors in New York, Los Angeles and Brussels (Hondagneu-Sotelo \& Estrada, 2011; Basinski, 2014; Voiculescu, 2014), and on informal recyclers/waste pickers in Canada and Europe (Wittmer \& Parizeau, 2018; Scheinberg et al., 2016).

\section{The case of Spain}

In Spain, the dominant idea of work has been gradually undermined as the various crises (1993-1995 and 20082015) have facilitated the approval of legal frameworks that have had the effect of making the labour market more flexible and precarious. Against this backdrop, one element stands out when we compare Spain with its neighbours. Unemployment is not only much higher than the European average, but it also affects certain groups to a much greater degree, above all Spain's youth, who present jobless figures in excess of $50 \%$ with $55 \%$ of those in employment holding a temporary contract (EPA 4T. 2017). This emphasises the fact that the labour transition, especially that of young Spaniards, following the shift in the socio-economic paradigm and the crisis of the welfare state, is much more intense than that in neighbouring. Thus, job instability is calling into question the basic pillars of social stability, including uncertainty in the long-term planning of life projects, increasing difficulty in developing a professional or occupational career in keeping with one's training and, ultimately, the loss of labour and citizen rights. The globalisation and liberalisation of markets have had a significant impact on the ways of organising work. In contrast with the rationality of the Keynesian-Fordist model, in which wage labour constituted a mechanism of citizen integration and personal stability, the new commercial logic prioritises market competitiveness, contributing in this way to the segmentation, fragmentation and individualisation of the world of work (Subirats, 2015). Adaptability to productive cycles and the progressive deregulation of employment today characterise the management of labour in a context marked by economic fluctuations and by the flexibilisation of the labour factor characterised, in turn, by the insecurity and instability typical of a highly competitive capitalism that demands greater responsibility from the individual in their participation in the market.

These data confirm the enormous influence that the crisis and the evolution of the labour market are having on the population as a whole. The consequences are evident and are manifest in the deepening of new axes of social inequality related to an increasingly segmented labour market, where the most vulnerable social groups are trapped in a vicious circle between low-skilled jobs and unemployment. The result is a growing segmentation of the labour market where a group of "core" workers coexist - previously a majority and now increasingly fewer in number - and an increasingly larger collective of wage earners and "false" self-employed workers with an increasingly weaker link to the world of work.

In this context of crisis and precariousness, where formal work is ceasing to be the instrument for the redistribution of wealth par excellence, informal work has gained weight within Spain's economic structure. In Spain, if you are a foreigner and you wish to obtain a residence permit, you have to demonstrate that you have a job. There are two ways of going about this: being employed and having an employer willing to demonstrate that their firm can contract you; or being self-employed and being able to demonstrate this condition. In both situations, the Spanish State defines work, in keeping with the dominant model, as socially recognised activities. If, for example, a chaterrero seeks a residence permit from a Spanish consulate and states that he or she is employed collecting reusable or recyclable materials, it is more than likely that their permit will be denied as this activity is not considered a job, let alone a formal and desirable job. 
The city of Barcelona, with a GDP of 76,604.8 million euros in 2016, according to Barcelona City Hall sources, represents approximately $6 \%$ of the total Spanish economy and has an unemployment rate of $11.5 \%$ (EPA 4T, 2016). Most of the employment in the city is concentrated in the services sector $(76.2 \%)$ and, of this, just over $50 \%$ are activities associated with the city's tourism industry (trade, repairs, hospitality, financial activities, real estate, administrative and auxiliary services, sports and cultural activities and others). Alongside these regulated labour activities (many of them quite precarious), there are others that do not fall within the dominant model of work and which are directly or indirectly associated with tourism.

Among these, the most visible are street vendors (especially beer), chatarreros, street and underground buskers, living statues, beach masseurs, cycle rickshaw drivers, caricaturists, etc. There are not much data about informal jobs in Barcelona or in Spain but, in general, they are activities that lie outside general public knowledge and that are systematically hidden in the murky shadows of the underground economy. And although the information available on work in the city says little about workers that fall outside the dominant framework, there are indications that it is a phenomenon that extends beyond traditional connotations of groups of marginal jobs and that it presents specific city characteristics, related, that is, to one of its main activities, in this case, tourism.

Barcelona's "other jobs" have a long unwritten, or at least, undisclosed history. The beginnings of the activity of the chatarreros can be traced back to the 18th century, when they were known as traperos (or rag pickers), while street vendors had been known since the 13th century, their activity concentrating around the Belcaire Market, today one of the city's tourist attractions. However, it is a story in which the city constantly regulates and penalises old and new activities alike, turning historically recognised activities into "other jobs" and at the same time, in many instances, it ends up displacing and disarticulating the workers who perform them. This stigmatisation, which penalises informal work, contributes to the idea that there is an exclusive mode for recognising work and for managing all those activities that fall outside the dominant frame of formal work.

\section{A case study: The sub-Saharan chatarreros of the city of Barcelona}

Barcelona's chatarreros are men and women that work in the streets, scavenging for materials and objects that their owners no longer want and which they believe have some recoverable value. Although the name refers specifically to the scrap objects (chatarra) that they collect, a better definition for the task they perform would be "reclaimers". In fact, they might be defined as 'miners of the city', extracting recyclable materials and re-usable objects from among the urban solid waste, but unlike miners neither their work nor the value they add to the materials is recognised. In other words, while the copper in the hands of a miner is considered raw material, the copper in the hands of a chatarrero is part of the city's waste. This is indicative of the social meaning attached to the work of the chatarreros and the relationship they have with the objects that surround them (Appadurai, 1991).

More often than not, chatarreros are afforded no social recognition and are not considered as having an occupation. They are seen as a social problem, undertaking a spontaneous activity to ensure their survival, a task for the destitute or, in the worst of cases, an activity associated with delinquency and crime. Many are the stigmas attached to them: poor, undocumented, immigrants, unemployed, marginal, precarious, chaotic, dirty, etc. And many of these social badges pinned to them derive from an ignorance of the communities that perform this economic activity - communities that are hidden away and which, therefore, are largely, invisible - and, more particularly, of the rationale underpinning their work and of the mechanisms and strategies that they adhere to.

The tasks they perform might be included within an occupation that could be defined as informal recycling': recycling, because it is governed by an economic and business rationale that seeks to recycle, or endow with a new use, the materials collected by the chatarreros; and, informal, because the state intervenes little if at all in the activity, with all the consequences that that entails.

The informal recycling performed by the chatarreros can be classed as a precarious job of global characteristics. In most big cities in the world, scrap metal waste pickers dedicate their energies to selecting, separating, transporting and selling recyclable materials and re-usable items from the rubbish (Samson, 2009). In large urban areas, many people are engaged in this activity and, in recent years, it has actually been regulated in some of the world's cities, based on the implementation of waste management processes with separation at source. However, there are 
marked differences in the way these practices are presented in central and peripheral economies: primarily, reflecting the logic of the markets, the social value that this type of work can claim for itself, its association with phenomena of international migration and social exclusion and the priority that each city attaches to its economic activities.

The case of Barcelona is characterised by economic crisis, high unemployment and high rates of international migration and is centred on groups that are denied any access to the labour market, who create informal organisational structures around the activities they conduct. There are no reliable data about the people that are engaged in the 'reclaiming' of materials, and only broad generalisations can be made about them. Broadly speaking, it is a predominantly immigrant population (in this particular case originating from the sub-Sahara) which has developed its own infrastructure (a large factory building and occupied warehouses) to carry out their work (Mendoza, 2014).

Historically, the work of chatarreros in Barcelona has been associated with different groups. Its origins can be traced back to the eighteenth century when the activity was limited to the collecting of old rags. After the First World War, and as a consequence of the prevailing scarcity of goods, there was a diversification in the materials collected as the job came to resemble that of a second-hand dealer. In the Second Republic, the trade was regulated and working conditions were negotiated with Barcelona's Sindicat de Drapaires (Trade Union of Rag Pickers) and with the Civil War finished, the job gained a certain social importance given the need to recover materials and objects after the destruction of the city (Fernandez Valenti). More recently, with the sharp rise in immigration since the start of the 21 stcentury, this trade, which had traditionally been associated with Roma groups, has been taken over by immigrants from Eastern Europe and, above all, by people of sub-Saharan origin, who make up the group studied in this paper.

The main features of the specific world studied here - according to the information provided by the chatarreros themselves, the press and various legal documents (Eviction for non-payment, 2013 section C; Síndic de Greuges de Catalunya, 2014) - show that the number of people working in the factory building in Puigcerdá Street stood at around 700, of whom 300 lived on the site. To this we need to add the other groups of chatarreros from other nearby warehouses or from other parts of the city. Most of them are Senegalese, although verification of nationality is complex as many of them do not have a residence permit and do not declare their nationality of origin as a migratory strategy to avoid repatriation. The number of women engaged in the activity is low, which means the group is made up predominantly of men, without any family, and with no possibilities of entering the wage labour market.

\subsection{The work of the sub-Saharan chatarreros}

The work of the chatarreros in Barcelona is based on a group of activities that presents its own clear division of functions: including the selection, separation, transport, improvement and selling of recyclable materials and reusable objects. It is a global urban activity intimately related to the logic of high consumption and waste production (Samson, 2009).

In the factory building in Puigcerdà Street in the barrio of Poblenou there is a constant coming and going of people. On any given day, various groups of chatarreros can be seen filling a container - in all likelihood supplied by a firm that buys the product and then sells it on for use in the industry - and by many other individuals weighing materials at various points throughout the factory building, businesses that buy almost all the materials supplied by the reclaimers.

The work of the chatarrero is an activity that combines intensive labour and a work environment in which chance plays a primordial role. The sources of the materials, the collection schedules of furniture and other junk, the climatic conditions or the zone of the city assigned to each chatarrero are all variables that determine the daily route and daily wage. Similarly, the strategies of each chatarrero may vary depending on the sites where they go seeking chatarra and the schedules assigned to each. Collection is based on a constant search "from one source to the next": that is, from one rubbish skip to the next, construction sites or places where scrap might accumulate. As such, it is not a linear activity but rather one that means the reclaimers have to visit the sources and observe, 
ask around and, if necessary, wait. Figure 1 shows a typical route taken by the chatarreros working at the Puigcerdà factory.

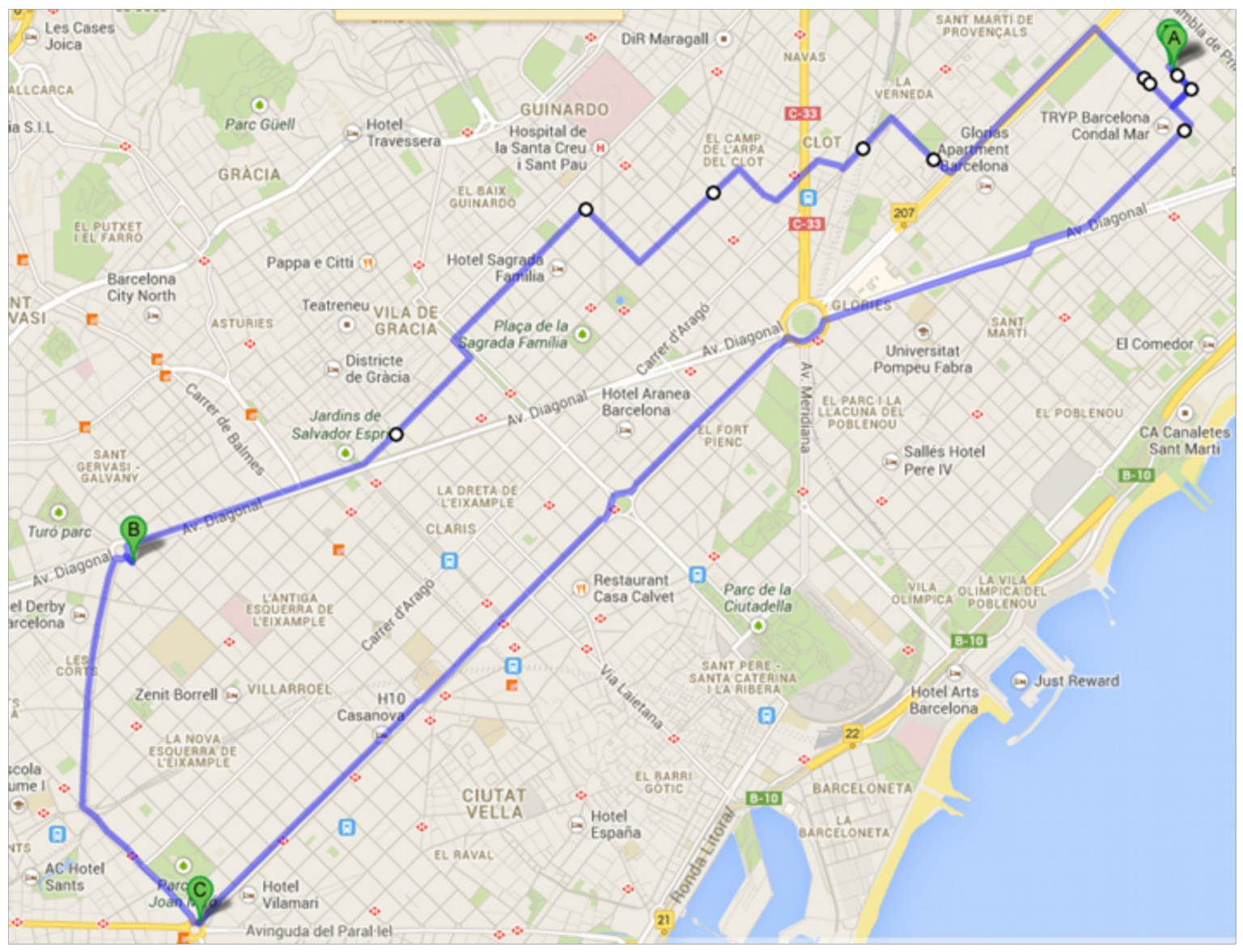

Figure 1. Google Maps

"It all depends, one day you might go out and walk, from seven in the morning to seven in the evening and not find a thing, another day you can go out and make 100 euros, it's all down to luck, no one can tell you (what) you're going to find, for example, today, you'll find such and such a thing. It's like this, I leave my house, but you don't know a thing, not even if you're goingto be run down by a car, but every day I'm out looking and I find something. If I get home safe, I thank. God, I'm home, because it's never easy". (Interview no 4)

Moreover, the chatarreros interviewed report that the activity does not allow them to save any money, which means no surplus earnings that can be sent to their families. What they earn each day simply allows them to go out and continue working the next day, covering their accommodation, food and transport.

"The only things I think about are getting out into the streets - so I get my trolley and walk - and about what I find and what I can sell the same day and what they'll pay me, with that I can continue to make a living". (Interview no 4 )

This situation, they explain, has been exacerbated by the crisis, as the production of scrap metal has fallen and competition has grown, because many sub-Saharans who had previously worked in the construction sector are now "self-employed" and working in "informal recycling".

"We don't earn a thing from our work, a little to pay for a room, to eat and nothing more (...) not now (sending money back to the family), because now there is no work (materials on the streets), before yes". (Interview $\mathrm{n}^{\circ} 7$ )

"There was a time when a lot of people made a bit of money and you could send some back to the family. Two years ago, you could reach the end of the month and have made 700 or 800 euros, but now with what you earn you don't have enough for that". (Interview n ${ }^{\circ}$ ) 


\subsection{The social construction of the activity}

The forging of ties of solidarity and support is relatively strong among the chatarreros and, although it may differ from one group to another, they show a high degree of internal cohesion.

"The relationship with the other chatarreros is of friendship, brotherbood, work, they're colleagues, compatriots, all this, because our parents aren't here, and normally we don't come with our own true brothers, we come alone, and having to share the same conditions makes us people of the same class, and this creates something that is very strong, bere you don't mess with an African and get away with it". (Interview $\mathrm{n}^{\circ} 1$ )

Likewise, the relationship they establish with the social environment is generally good. Typical of this is the support the chatarreros obtained from the Poblenou neighbourhood association in fighting their eviction from the Puigcerdà factory (Eviction for non-payment, 2013 section C). The same is true of the chatarreros of Bogatell (a neighbouring warehouse). And although there have been cases of racism, the chatarreros see them as totally isolated incidents.

"The relationship with those outside the factory is very good, our neighbours have always treated us well, there's a small group of people who don't like us at all, we understand that, here - I don't know if there are 27 thousand or 30 thousand inhabitants, those who reject us don't number more than 10, but we're respectful, it doesn't stop us getting on with our lives". (Interview no 1)

Another actor needed to understand the organization of the activity is the intermediary - the link in the chain that connects this informal occupation with the formal industrial processes of recycling - and whose function is to buy, separate and accumulate the materials. The chatarreros establish a relationship of cooperation with the intermediaries, but also one built on trust and relative dependence. In most cases, the intermediary is a small firm with a warehouse that buys various types of material. At the same time, this firm also acts as an agent, providing a link between recycling firms and the chatarreros, although it does so from a position of dominance which means it is a facilitator of work but, at the same time, it is able to hide the relationship between capital and labour, a relationship of brokerage that is underpinned by forms of exploitation, corruption and the accumulation of power (Stovel \& Shaw, 2012). The intermediary, therefore, plays a dual role based on both trust and dependence, forging most of the time an oligopolistic position in which the chatarrero has no alternative other than to sell his material to that firm.

"The scrap metal is weighed properly, (...) I have a number of fixed customers they know me, I know them, I don't think. they're likely to cheat me. Good quality copper fetches 4.80, maybe 4.50 to 4.40 (euros), depends on the person who buys it. (...) You can sell at another price, but (you bave) to sell to them". (Interview $n^{\circ} 6$ )

The social construction of the work of the chatarrero and the people who perform this activity is socially negative. Both their external projection in the news media and the social perception they have of themselves does not help to recognize their activity as "normalised" work. On the contrary, the activity is perceived socially as a circumstantial occupation with which it is not possible to create elements of identification. And although it is a physical, manual job, from a social point of view, it carries the stigma of dishonour, shame and the loss of self-respect.

"I didn't want to walk. the streets with this shopping trolley because I was ashamed, my workmate tells me it's a job like all the others, but what happens is that you're better off not looking at anyone, you have to worry about yourself". (Interview no 3)

Ultimately, a constant idea is expressed about this type of activity: "it's only a temporary situation". And although it is a job that shares many characteristics with other jobs, it is identified as an activity performed solely to guarantee self-preservation and the reproduction of the species, and not as one that transforms labour into work (Arendt, 2009). This reality allows us to understand just how perverse the interpretative model of the labour market is, presenting itself as a scenario in which only those who are socially and economically recognised can participate. 


\subsection{Social recognition of the activity}

From a supply and demand perspective, the occupation of the chatarrero can be considered as that of a supplier of raw materials for certain productive tasks. In contrast, if the focus is placed on the social function of the activity, fundamental differences emerge. Barcelona's City Hall programme of separating and collecting solid waste encourages the separation of materials at source (in rubbish skips, on the street, on construction sites, etc.) and, from there, it is the service providers that manage the processing of waste. The implication is that the work of the chatarrero can be considered a surplus-job, where the collection of materials forms part of a subsistence strategy in the framework of an economy with high unemployment. From this it can be deduced that this work is labour intensive and, at the same time, unproductive, since it is a job that overlaps with the activity of the companies hired by City Hall. However, the existence in the city of an economic space of waste management based on the work of the chatarreros is undeniable. This is due, in the main, to the fact that their activity (suppliers of raw materials) is complemented by two parallel functions: recovering the exchange-value and use-value of certain objects and reducing the purchase costs of some goods needed by a part of the population with very few economic resources. However, in neither case is it considered a productive activity, even if it involves activities inherent to the capitalist system.

But, undoubtedly, the interpretation that most closely defines this activity is the idea of social distress, since it is this which hides the many facets of this job. Instead of recognizing this activity, the City Hall, the chatarreros' neighbours and the news media only know how to seek welfare support for these people, without understanding that such actions serve solely to make any other facet of the chatarrero's work invisible and to strengthen the image of an economic activity of subsistence and survival. Moreover, this perception challenges the idea that the chatarreros have regarding their social function, which emphasizes their potential as workers and their need to achieve economic independence via their work.

\subsection{Capital as the representation of work}

There are two ways to conceal work: the concrete and the abstract. The concrete way is the way that we have described up to this point and, basically, it refers to forms of the non-social recognition of an activity, while the abstract takes a subtler approach - it is a way of concealment that refers to the non-recognition of capital as an expression of the materialisation of work.

Capital is the way in which surplus labour is expressed. It is the value created by an economic activity that, by means of a process of accumulation, serves to reproduce the initial conditions of the same. As Hernando de Soto et al. (1987) points out in his extensive research on informality in Peru, capital needs institutional support and State recognition. His research shows how lengthy bureaucratic processes - both legal and illegal - generate spaces of economic life that fall outside State regulation and, without this legalization, the capital lacks value (de Soto et al., 1987; Hart, 2000).

What is clear is that capital needs to have institutional support, and this support is, ultimately, a way of recognizing the work needed to be able to accumulate it. In the case of Barcelona's sub-Saharan chatarreros, what is self-evident is the lack of support for the capital that these workers have constructed.

There is an ongoing debate as to whether small productive units meet the requirements to be recognised as capitalists - that is, that their objective is to accumulate capital. In some interpretations of self-employment and small business, it is claimed that the latter can be considered a type of outsourced work where the relationship between capital and labour is erased, so that these activities would not concentrate capital, given that the entities that concentrate it are the largest companies for which they work. In the case of the chatarreros, it is undeniable that the necessary conditions exist to reproduce the activity. And while it cannot be claimed that they play the role of capitalist accumulators, the need to invest in certain goods so as to be able to carry out the activity can be interpreted as the necessary capital.

In relation to the chatarreros, there are two examples regarding the absence of institutional support when it comes to accumulating capital. The first is the one witnessed following their eviction from the Puigcerdà factory in 
2013. The chatarreros might be said to have been using the factory building illegitimately, and it might be said that its use as a means of production was questionable from a legal perspective. However, what is also clear is that all the capital that the chatarreros accumulated there was legitimately theirs and that the materials accumulated, the conditioning of the factory for production, the social structures of production and the "know-how" accumulated in the infrastructure where they sold the recyclable materials and the reusable objects were not recognised. The measures adopted in their eviction did nothing to safeguard the chatarreros' capital, as they would in certain sectors of the traditional market, where the State, for the sake of the common good, seeks to safeguard the capital accumulated (as happened in Spain with the bailout of the banks in the middle of the economic crisis). This did not happen with the chatarreros, as one of their spokespersons explained in a press conference offered a few days after the eviction:

"Many of our things have been left in the factory, it's been two long years of struggle, two years retrieving things, we've collected many things together, half these things were left in the factory, those things are our things, and now they're tearing down the factory on top of our things, the City Hall must compensate us for those things in some way, compensate those people who've been working for almost two years". (Interview $\mathrm{n}^{\circ} 6$ )

In this case, the non-institutional recognition of capital reduces the reproduction of the activity to a form that is less than simple. That is, the elements needed to carry out this activity were not replaced by the work done. And as many studies on informality point out, in its most precarious forms, this can lead to forms of work in which income is not differentiated from wages and profits. Thus, at the end of an extended period, it is evident that the workers do not pay for all of their work, nor do they obtain any profit and, therefore, they are slowly consuming the capital invested (Alba Vega \& Kruijt, 1995).

\subsection{The chatarreros, the other workers (The relation between subject and work)}

Against the backdrop of economic crisis, it seems logical that structural problems that previously have not always been perceptible should emerge. In all capitalist societies there are labour and economic activities that do not form part of the dominant structures of the labour market and that become magnified in times of crisis. Informal jobs are not new, they are cyclical and highlight the existence of a very precarious part of the population whose work is not even recognised. As has been reiterated throughout this article, this reality has two complementary interpretations - one economic in nature; the other related to social control.

On the one hand, the activity of the chatarreros is functional to the logic of the market and is a source of cheap labour in highly labour-intensive activities. But, on the other hand, the chatarreros are a group that perform unproductive work and to which the mechanisms of social control and the logic of barriers to the integration of immigrant groups must be applied (Gálvez, 2017).

The "other jobs" are not specific activities, nor economic forms that differ from those being exercised in the wider setting. They can simply go from being important occupations one moment to being an unrecognised activity or job the next. The case of the chatarreros is self-evident, and can be contrasted with cases described in various international studies (Medina, 2007; Samson, 2009; Scheinberg, 2012; GAIA, 2012). Moreover, the "other jobs", as exemplified in a number of different case studies, impact the current political landscape, given that the transversal nature of their demands surpasses the classic demands of the unions. The struggle of Barcelona's chatarreros are indistinguishable from those of the neighbourhood associations and social movements opposed to discrimination. And, in the same vein, the fight of the street vendors and the neighbourhood demands for the free use of public spaces and their condemnation of the city's tourism model can be associated with these struggles.

Equally, the cross-comparison of social variables is essential for a better understanding of the "other jobs" and the "other workers". Not only do we need to understand that the work of the chatarreros is stigmatised, but that the type of work has to be related with the specific groups that carry it out. Inequalities in the world of work are not only related to types of activity, but also to the actors that perform them. Therefore, not only are they activities that are hidden, or that are marginal, but the phenomenon is closely related to the groups that carry them out. The dominant model is not only constructed from the normative idea of work, but also from the 
person who fills the position (man-woman, youth-adult, black-white, resident-foreigner, etc.). And if in the case of gender it is perfectly - the wage gap between male and female work in Spain is approximately 24\% (UGT, 2015) - the same occurs in relation to the perception of the immigrant. Subject and work form part of the same relationship and we need to understand the correlation that exists between lack of income, institutional control, racism and labour market segmentation in the reproduction of the activity.

\section{Conclusions}

Since the beginning of the 21 st century, a paradigm shift has been recorded in the labour factor. This shift is intimately linked to the new economic context resulting from the process of economic globalisation and from the subsequent consequences of the great economic-financial crisis of 2008-2015. One of the factors that has impacted most in the deteriorating evolution of the labour market has been the growth in unemployment, the rise in job insecurity and the increase in the risk of poverty faced by broad swathes of the working classes, especially in the countries of southern Europe. However, if we look beyond the figures, it is evident that the world of work is a restricted space where only legal and quantifiable activities achieve formal recognition, while other jobs, those classed as "informal", remain largely invisible. In general, the labour market is a space made up of the wide range of occupations and activities performed in society but, at the same time, it is a space that excludes activities which lie outside the dominant paradigm (Pahl, 1991).

The concept of informal work cannot be explained by a single causal theory, it is highly heterogeneous and can be a highly negative burden for the worker to bear. It is a concept - fundamentally urban in nature - that is gaining growing academic relevance while, at the same time, it is an indicator of the inequality that manifests itself in various work, and even non-work, environments, being closely related with the reproductive labour of women in the home. Moreover, it is a functional model that absorbs labour when there is not enough employment and which manifests itself in terms of activities that do not present the characteristics of waged work, although the objects it pursues might be the same (hospitality sector, construction, etc.), or of those associated with (true or false) self-employment, as is the case of the work of the chatarreros.

The case exemplified by the chatarreros is that of a precarious job with evident global characteristics: in most big cities of the world, waste pickers select, separate, transport and sell recyclable materials and reusable articles from the rubbish (Samson, 2009). In large urban areas, many people are engaged in this activity and, in recent years, it has actually been regulated in some of the world's cities, based on the implementation of waste management processes with separation at source. However, there are marked differences in the way these practices are presented in central and peripheral economies: primarily, reflecting the logic of the markets, the social value that this type of work can claim for itself, its association with phenomena of international migration and social exclusion and the priority that each city attaches to its economic activities.

The social construction of the work of the chatarrero and associated groups is a key element for interpreting informal jobs in contexts such as those studied here. It needs to be stressed that the work of the chatarreros is socially constructed by the type of work they perform and by the actors who perform it. Thus, their work is not solely about activities which are hidden, or that are marginal, but it is also closely related to the groups that carry them out. Therefore, not only are they activities that are hidden, or that are marginal, but the phenomenon is closely related to the groups that carry them out. The dominant model is not only constructed from the normative idea of work, but also from the person who fills the position (man-woman, young-adult, black-white, resident-foreigner, etc.). As such, the hegemonic model is not only constructed on the basis of the normative idea of work, but also on the basis of who performs it (man-woman, youth-adult, black-white, residentforeigner, etc.). For this reason, its external projection in the news media as well as the social construction the media make of their work does not help their activity to be recognized as a "normalized" job. Quite the contrary, it is perceived socially as a circumstantial occupation with which it is not possible to create elements of identification. And although it is an activity with physical and manual characteristics similar to many other formal jobs, from a social point of view only the "humanitarian needs" associated with these groups are recognized as their sole interpretative and explanatory facet. But the lack of social recognition afforded informal jobs does not sufficiently explain the mechanisms that operate in their concealment. In the case of Barcelona's chatarreros, one 
of the determinants of these mechanisms of concealment is the difficulty encountered in accumulating capital from their work, and this fact is largely determined by the absence of institutional support for the activation of the process of capital accumulation and the reproduction of work activity.

Current studies of informal jobs in Europe are sufficient in number for much broader conclusions to be drawn, as is the case of the large body of research on this type of work on the African continent (Kinyanjui, 2014) and in Latin America (de la Garzo Toledo, 2011); yet, probably, the limitations of this paper are directly related to its capacity for comparison. However, the reality of the situation described seems to indicate a clear path for future researchers: specifically, there is a need to consider such aspects as social recognition, the management of informal work in big cities and the social construction of new models of work and their recognition and relationship with specific groups of the population.

\section{Declaration of Conflicting Interests}

The authors declared no potential conflicts of interest with respect to the research, authorship, and/or publication of this article.

\section{Funding}

The authors received no financial support for the research, authorship, and/or publication of this article.

\section{References}

Alba Vega, C., \& Kruijt, D. (1995). La utilidad de lo minúsculo: Informalidad y microempresa en México y los países andinos. México: El Colegio de México.

Appadurai, A. (1991). Introducción: Las mercancias y la política de valor. En A. Appadurai (Ed.), La vida social de las cosas: Perspectiva cultural de las mercancias (págs. 17-88). México: Grijalbo.

Arendt, H. (2009). La condición humana. Barcelona: Paidós.

Basinski, S. (2014). Hot Dogs, Hipsters, and Xenophobia: Immigrant Street Food Vendors in New York. Social Research, 81(2), 397-408.

Bauman, Z. (2004). Modernidad líquida. Buenos Aires: Fondo de Cultura Económica.

Beck, U. (2000). The Brave New World of Work. Oxford: Polity Press.

Beck, U. (2002). Individualization. Londres: Individualization.

Castells, M. (2000). La era de la información (Vol. 1). Madrid: Alianza Editorial.

Castillo, J.J. (1998). A la busqueda del trabajo perdido. Madrid: Tecnos.

Castillo, J.J., \& de la Garza Toledo, E. (2000). Tratado Latinoamerica de Sociología del Trabajo. Méjico: Fondo de Cultura Económica.

Chant, S., \& Pedwell, C. (2008). Women, gender and the informal economy: An assessment of ILO research and suggested ways forward. Geneva: ILO.

Chen, M. (2012). The Informal Economy: Definitions, Theories and Policies. Cambridge: Wiego.

Cimolli, M., Primi, A., \& Pugno, M. (2006). Un modelo de bajo crecimiento: La informalidad como restricción estructural. Revista de la CEPAL, (88), 89-107.

Climent, V. (2015). La nueva pobreza en el mercado de trabajo. Intangible Capital, 11(2), 270-283.

Credit Suisse (2015). Global Wealth Report 2015. Zurich: Credit Suisse AG.

de la Garza Toledo, E. (2001). Problemas clásicos y actuales de la crisis del trabajo. En E. de la Garza Toledo, \& J. C. Neffa (Ed.), El trabajo del futuro, el futuro del trabajo. Buenos Aires: Clacso.

de la Garza Toledo, E. (2011). Problemas conceptuales, relaciones de trabajo y derechos laborales de los trabajadores informales. Revista Internacional de Estadística y Geografia, 2(3), 5-15.

de la Garzo Toledo, E. (2011). Trabajo no clásico y acción colectiva (Vol. 1). México DF: Plaza y Valdes. 
de Soto, H., Ghersi, E., \& Ghibellini, M. (1987). El otro sendero: la revolución informal. Lima: Oveja Negra.

Denzin, N., \& Lincoln, Y. (2012). Manual de investigación cualitativa. Barcelona: Gedisa.

Edelbache, M.r., Kratcoski, P.C., \& Dobovsek, B. (Edits.). (2016). Corruption, Fraud, Organized Crime, and the Shadow Economy. Boca Ratón: CRC Press.

Esping-Andersen, G. (2000). Fundamentos sociales de las economias postindustriales. Barcelona: Ariel.

Espinosa, H. (2017). El mercadillo rebelde de Barcelona. Prácticas antidisciplinarias en la ciudad mercancía. Quaderns-e, 1(22), 67-87.

Eviction for non-payment (Desahucio por precario), Juicio verbal 411 (Juzgado Primera Instancia 21 Barcelona 17 de Junio de 2013 sec. C).

Fernandez Valentí, R. (s.f.). El tranvía 48. Retrieved on May 5 ${ }^{\text {th }}$, 2018 from: eltranvia48.blogspot.com.es

Fernández, L., Pena Pan, J., \& Rey Manzón, P. (2014). WAW: Waste Pickers Around the World Database. WIEGO.

GAIA (2012). On the Road to Zero Waste: Successes and Lessons From Arround the World. GAIA.

Gálvez, J. (March 20 $\left.{ }^{\text {th }}, 2017\right)$. Miles de inmigrantes 'encarcelados' para nada. Retrieved on 21 de March $21^{\text {st }}, 2017$ from: http://politica.elpais.com/politica/2017/02/03/actualidad/1486132000_254307.html

Hart, K. (1973). Informal Income Opportunities and Urban Employment in Ghana. The Journal of Modern African Estudies, 11(1), 61-89. https://doi.org/10.1017/S0022278X00008089

Hart, K. (2000). The Memory Banck: Money in an Unequal World. Londres: Profile Books.

Hilbrandt, H., \& Richter, A. (2015). Reassembling austerity research. Ephemera, 15(1), 163-180.

Hondagneu-Sotelo, P., \& Estrada, E. (2011). Intersectional Dignities: Latino Immigrant Street Vendor Youth in Los Angeles. Journal of Contemporary Ethnography, 40(1), 102-131. https://doi.org/10.1177/0891241610387926

ILO (2002). El trabajo decente y la economía informal. Ginebra: OIT.

Kinyanjui, M.N. (2014). Women and the informal economy in urban Africa: From the margins to the centre. London: Zed Books.

Lazarte, R. (2000). El "sector informal” una revisión conceptual bibliográfica. (IIEc-UNAM, Ed.) Problemas del desarrollo, 31(121), 35-62.

McGovern, P. (2013). Contradictions at Work: A Critical Review. Sociology, 48(1), 1-18.

Medina, M. (2007). The World's Scavengers: Salving for Sustainable consuption and production. Lanham: Altamira Press.

Mendoza, I. (2014). Afrikalando in the gueto: Prácticas de reciclaje urbano en Barcelona. Tesis Máster, Universidad de Barcelona, Máster enAntropología i etnografía.

Miguélez, F., \& Torns, T. (1998). Introducción al análisis del trabajo y de la vida cotidiana. Papers, 55, 9-25. https://doi.org/10.5565/rev/papers.1930

Mingione, E. (1994). Las Sociedades Fragmentadas: Una Sociología de la Vida Económica Más Allá Del Paradigma Del Mercado. Madrid: Ministerio de Trabajo y Seguridad Social.

Misas, G. (1993). Desarrollo científico y teoría económica: nuevos retos para la enseñanza de la economía. Cuadernos de Economía, 13.

Noguera Ferrer, J.A. (1998). La transformación del concepto de trabajo en la teoría social (la aportación de las tradiciones marxistas). Barcelona: Universidad Autonoma de Barcelona.

Pahl, R. (1991). Divisiones del trabajo. Madrid: Ministerio de Trabajo y Seguridad Social.

Pfau-Effinger, B. (2017). Informal employment in the poor European periphery. International Journal of Sociology, 37(7-8), 387-399. https://doi.org/10.1108/IJSSP-07-2016-0080

Polanyi, K. (1989). La Gran transformación: crítica del liberalismo económico. Madrid: La Piqueta.

Ponsaers, P., Shapland, J., \& Williams, C.C. (2008). Does the informal economy link to organised crime? International Journal of Social Economics, 35(9), 644-650. https://doi.org/10.1108/03068290810896262 
Portes, A., \& Sassen, S. (1987). Making it Underground: Comparative Material in Informal Sectorin Western Market Economies. American Journal of Sociology, 93(1), 30-61. https://doi.org/10.1086/228705

Portes, A., \& Zhou, M. (1996). Self-Employment and the Earnings of Immigrants. American Sociological Review, 61(2), 219-230. https://doi.org/10.2307/2096332

Pradel-Miquel, M. (2016). Crisis, (re-)informalization processes and protest: The case of Barcelona. Current Sociology, 65(2) 1-13.

Rifkin, J. (1996). El fin del trabajo. Nuevas tecnologías contra puestos de trabajo: El nacimiento de una nueva era. Barcelona: Paidós.

Samson, M. (2009). Rechazando a ser excluidos: la organización de los recicladores en el mundo. Cambridge: WIEGO.

Sariento, H., Tilly, C., de la Garza Toledo, E., \& Gayosso Ramírez, J.L. (2016). The unexpected power of informal workers in the pulblic square: A comparision of mexican and US organizing models. International Labor and Working-Class History, 89, 131-152. https://doi.org/10.1017/S0147547915000368

Sassen, S. (1988). New York City's Informal Economy. Volume IV. 1988-89 - Conference on Comparative Ethnicity: The Conference Papers, June 1988. Los Angeles: University of California.

Scheinberg, A. (2012). Informal Sector Integration and High Performance Recycling: Evidence from 20 Cities. Cambridge: WIEGO.

Scheinberg, A., Nesic, J., Savain, R., Luppi, P., Sinnott, P., Petean, F., et al.. (2016). From collision to collaboration - Integrating informal recyclers and re-use operators in Europe: A review. Waste Management and Research, 34(9), 820-839. https://doi.org/10.1177/0734242X16657608

Schneider, F. (2018). Size and development of the shadow economy of 31 European and 5 other OECD countries from 2003 to 2013: A further decline. Retrieved from: http://www.econ.jku.at/members/Schneider/

Shapland, J., \& Heyes, J. (2017). How close are formal and informal work?. International Journal of Sociology and Social Policy, 37(7/8), 374-386. https://doi.org/10.1108/IJSSP-06-2016-0071

Síndic de Greuges de Catalunya (2014). Informe al Parlamento 2013. Barcelona: Síndic de Greuges.

Siqueira, C.E. (2016). Does Informal Employment Exist in the United States and Other Developed Countries?. NEW SOLUTIONS: A Journal of Environmental and Occupational Health Policy, 26(2), 337-339. https://doi.org/10.1177/1048291116650974

Stovel, K., \& Shaw, L. (2012). Brokerage. The Annual Review of Sociology, 38, 139-158. https://doi.org/10.1146/annurev-soc-081309-150054

Subirats, J. (2015). Todo se mueve. Acción colectiva, acción conectiva. Movimientos, partidos e instituciones. Revista Española de Sociología, 24, 123-131.

UGT (2015). Trabajar igual, cobrar igual. UGT.

Voiculescu, C. (2014). Voyagers of the smooth space. Navigating emotional landscapes: Roma street vendors in Scotland. Emotion, Space and Society, 13, 24-31. https://doi.org/10.1016/j.emospa.2014.05.003

Wallerstein, I. (1988). El capitalismo histórico. Madrid: Siglo XXI Editores.

Wallerstein, I. (2013). Structural crisis, or why capitalist may no longer find capitalism rewarding. En I. Wallerstein, C. Randall, M. Michael, G. Derlugian, \& C. Calhoun, Does capitalisn have a future? (pp. 9-37). New York: Oxford University Press.

Williams, C.C. (2013). Tackling Europe's informal economy: A critical evaluation of the neo-liberal de-regulatory perspective. Journal of Contemporary European Research, 9(3), 261-279.

Wittmer, J., \& Parizeau, K. (2018). Informal Recyclers' Health Inequities in Vancouver, BC. NEW SOLUTIONS: A Journal of Environmental and Occupational Health Policy, 28(2), 1-23. https://doi.org/10.1177/1048291118777845 


\section{Versión en español}

Título: Un análisis del trabajo informal: El caso de los chatarreros subsaharianos en la ciudad de Barcelona

\section{Resumen}

Objeto: El presente artículo tiene por objeto analizar el marco laboral del trabajo "informal" y sus implicaciones sociales a través de un estudio de caso en la ciudad de Barcelona: Los chatarreros subsaharianos

Diseño/metodología/enfoque: En la presente investigación se ha llevado a cabo un análisis comparado de las aportaciones teóricas del trabajo informal ylas condiciones sociales y de vida de los chatarreros sub-saharianos en Barcelona. Por lo que se refiere a fuentes primarias, se han realizado un total de 12 entrevistas (10 entrevistas a chatarreros y 2 a líderes vecinales) y se ha llevado a cabo un intenso trabajo de campo etnográfico entre febrero y agosto de 2013.

Aportaciones y resultados: Barcelona, como otras grandes ciudades del norte global, y muy especialmente tras la gran crisis de 2008-2015, ha experimentado un gran crecimiento del trabajo informal que está directamente relacionado con la principal actividad económica de la ciudad, que es el turismo. Históricamente, los trabajadores informales han sido sistemáticamente ignorados, puesto que el único trabajo reconocido es el legal o formal. Sin embargo, los grandes cambios económicos de los últimos 20 años han generado una transformación muy importante del Mercado de Trabajo que ha provocado un intenso proceso de segmentación y deprecarización del mundo del trabajo y un fuerte incremento del trabajo informal. En esta investigación se analizan tres puntos que son trascendentales para el entendimiento de los otros trabajos: reconocimiento del trabajo; capitalización del trabajo y la relación entre sujeto y trabajo.

Limitaciones: Esta investigación recoge un caso práctico que es el de los chatarreros de Barcelona. No obstante, existen muchos otros ejemplos que por, la limitación de espacio, no pueden ser incluidos como: los vendedores ambulantes, los músicos de calle, las estatuas humanas, los dibujantes urbanos, etc...

Originalidad / Valor Añadido: Existe un cierto desconocimiento sobre la realidad del trabajo informal y sus consecuencias sociales. Esta investigación tiene por objeto facilitar una mayor comprensión del concepto teórico de la informalidad laboral e ilustrar, a través del estudio de caso de los chatarreros, cuál es la realidad económica y social de los trabajadores informales y su estrecha relación con variables como: pobreza, discriminación, inmigración, desarraigo y economía de subsistencia.

Palabras Clave: Trabajo informal, Pobreza, Condiciones Laborales, Inmigración, Discriminación

Códigos JEL: J46, I32, J81, F22, J71

\section{Para citar este artículo:}

Porras Bulla, J., \& Climent Sanjuán, V. (2018). Un análisis del trabajo informal: El caso de los chatarreros subsaharianos en la ciudad de Barcelona. Intangible Capital, 14(4), 536-568. https://doi.org/10.3926/ic.1335

\section{Introducción}

La crisis económica iniciada en el 2008 ha contribuido a acelerar el deterioro del mundo del trabajo del siglo XX. La flexibilidad, la deslocalización, la precariedad o el desempleo son los ingredientes que caracterizan el actual mercado de trabajo que está experimentando un proceso de transformación que tiene múltiples causalidades: 
cambio tecnológico (Castells, 2000), evolución de modernidad sólida a modernidad líquida (Bauman, 2004), o explicaciones más estructurales sobre los modos de acumulación (Wallerstein, 2013).

Enrique De la Garza (2001) lo describe como una crisis compuesta por varios procesos paralelos: desarrollo tecnológico, disminución del empleo industrial, aumento del empleo en servicios, desplazamiento de la producción a lugares de difícil vinculación entre trabajo y capital o cambios en las teorías dominantes de interpretación económica. Y la principal consecuencia es la pérdida de centralidad del trabajo en la sociedad postindustrial y la emergencia de dos argumentos enfrentados: cada día hay menos trabajo en nuestras sociedades (Rifkin, 1996) o cada día éste se oculta más (Castillo, 1998; Castillo \& de la Garza Toledo, 2000; Pahl, 1991).

En gran medida, la explicación sobre esta transformación se debe al creciente alejamiento entre el mundo del trabajo y la economía (Polanyi, 1989), distancia que puede fundamentarse en el hecho que la mayor parte del capital se produce en el sector financiero, sin relación causal con el mundo del trabajo. A modo de ejemplo la riqueza mundial en el 2015, según cálculos del Global Wealth Report (Credit Suisse, 2015), era de unos 250 billones de dólares y cerca del 50\% se localizaba en el sector financiero.

Sin embargo, más allá de las cifras, el mundo del trabajo es un espacio restringido donde sólo se contabilizan las actividades legales y cuantificables, mientras que los otros trabajos llevados a cabo por cuidadores, inmigrantes, desempleados, estudiantes, pensionistas, etc... son invisibles. En general, el mercado de trabajo es un espacio compuesto por un amplio abanico de ocupaciones y actividades llevadas a cabo en el seno de la sociedad. Pero, a la vez, es un espacio excluyente dónde muchas actividades, ajenas al paradigma dominante, no se encuentran representadas (Pahl, 1991). Por otra parte, la idea hegemónica sobre el trabajo no es constante sino que ha evolucionado a lo largo de los dos últimos siglos y su impacto ha sido diferente en función del territorio o el momento histórico examinado (Wallerstein, 1988).

No obstante, en el momento actual, es cada vez más complejo definir la forma que tiene el modelo hegemónico de trabajo, puesto que la creciente flexibilidad laboral y los cambios producidos en la relación capital-trabajo han provocado un punto de ruptura entre el modelo clásico industrial-asalariado y un modelo emergente muy ligado a la globalización económica, donde elementos como las dinámicas urbanas, la migración o el desempleo configuran movimientos transversales en las grandes ciudades (Portes \& Sassen, 1987).

Uno de los elementos determinantes de la crisis del mundo laboral es la creciente importancia del trabajo informal en las grandes ciudades. Y aunque existen pocos datos directos desagregados Schneider, a partir del Multiple Indicators and Multiple Courses, calcula que aproximadamente el 18.5\% de la economía española está sumergida (2018), a lo que debe sumarse que el trabajo informal es cada vez más frecuente y más complejo. De hecho, en Barcelona, como en cualquier otra gran ciudad, sólo es necesario pasear por sus calles para observar la amplia presencia del trabajo informal: chatarreros, vendedores ambulantes, bicitaxistas, lateros, vendedores de globos, músicos de calle, estatuas humanas, retratistas, bailarines, afiladores de cuchillos, repartidores de publicidad, etc....

Esta investigación trata de dar cuenta de este fenómeno a través del caso de los chatarreros sub-saharianos en Barcelona, ejemplo típico de trabajo informal que se repite en la mayor parte de grandes ciudades del mundo (Fernández, Pena Pan \& Rey Manzón, 2014). El trabajo de campo se desarrolla en el año 2013 mientras se estaba llevando a cabo el proceso de desahucio de la nave industrial ocupada de la calle Puigcerdà en el barrio de Poblenou (zona de alta gentrificación de la ciudad). Este lugar era el principal punto de concentración de los chatarreros sub-saharianos en la ciudad y en la nave convivían un gran número de personas de diferentes nacionalidades, aunque la mayoría era de origen senegalés.

La nave de la Calle Puigcerdà estaba compuesta por un grupo de bodegas dispuestas a lo largo de una calle central, donde cada una de ellas tenía su entrada principal. Cada bodega tenía asignada una función concreta dentro de una división del trabajo específica como: la separación de metales, la acumulación de productos de reuso o la prestación de servicios como bar, peluquería o restaurante. Y aunque, en la mayor parte de ellas, las actividades productivas giraban en torno al mejoramiento y almacenamiento de materiales u objetos de re-uso. 
Cada bodega se podía identificar como una unidad productiva, con múltiples tipos de propiedad, solidaridad, cooperación y jerarquía interna.

Una vez finalizado el desahucio en julio de 2013, los chatarreros fueron desplazados hacia otros enclaves, contribuyendo a la desarticulación de la comunidad y de sus reclamos políticos. Esta investigación se llevó a cabo tres meses antes y dos despuésdel desalojo. Parte de una metodología cualitativa que utiliza la triangulación de información (Denzin \& Lincoln, 2012) a partir de observación etnográfica, análisis de medios de comunicación y 12 entrevistas (10 entrevistas a chatarreros y 2 a líderes vecinales). El grueso de la información, discursos y datos que contiene este artículo provienen de tres técnicas de investigación: observación participante, entrevistas semiestructuradas y análisis de medios de comunicación. La entrevista semi-estructurada retoma tres niveles de aproximación que buscan estudiar el trabajo en un sentido amplio (Miguélez \& Torns, 1998): el primero referido a los tiempos (productivo-reproductivo-tiempo libre y trayectoria vital); el segundo referido a los niveles de socialización; y el tercero a las estructuras de sentido. En el caso de la observación etnográfica se llevó a cabo desde febrero hasta agosto de 2013en reuniones, marchas, eventos antes y después del desalojo de la nave de Puigcerdà (julio 2013). El análisis de medios de comunicación realizado parte de una matriz que corresponde con los periodos de la observación participante, y se construye a partir de las diferentes temáticas periodísticas preexistentes (policial, espacio público, política, colectivo, comercio, asociaciones en contra). La selección de artículos parte de dos lógicas: una transversal, que ocupa toda la línea de tiempo, y otra que se centra en los momentos de alta producción de contenidos (como son las diferentes manifestaciones anteriores al desalojo, el momento del desalojo y las protestas posteriores). Los medios seleccionados obedecen a un arco político y territorial que permite el entendimiento de la construcción social de las actividades y sus ejecutores (El País, La Vanguardia, El Periódico, El Diario y La Directa). Finalmente, el análisis de estas tres fuentes de información se da a partir de la siguiente matriz:

1. Tiempos: caracterización básica de tiempos; articulación productivo-reproductivo-tiempo libre; articulación trayectoria de vida.

2. Socialización: construcción del sujeto; construcción del "nosotros"; construcción del otro.

3. Sentido: trabajo, capital; reconocimiento, organización, regularización.

\section{El nuevo contexto social del mercado de trabajo}

Obviamente, el cambio de paradigma del factor trabajo está muy relacionado con el nuevo contexto económico generado por la globalización económica y por las posteriores consecuencias de la gran crisis económicofinanciera del 2008-2015. Uno de los factores que más ha impactado en el deterioro y en la evolución del mercado de trabajo ha sido el incremento del desempleo, la consolidación de la precariedad laboral estructural y el incremento del riesgo de pobreza de amplias capas de las clases trabajadoras, especialmente, en los países del sur de Europa. Hasta los años noventa, el hecho de tener un empleo remunerado constituía un factor clave de integración social y de estabilidad económica y los perfiles tradicionales de pobreza siempre habían estado asociados a la vejez, la inmigración, el desempleo o la actividad laboral sumergida. Sin embargo, a partir de los noventa se observa como el riesgo de pobreza afecta a un número creciente de colectivos sociales que no han abandonado el mercado de trabajo (o entran y salen continuamente) y que sufren una creciente precarización de sus condiciones laborales que los convierte de facto en nuevos pobres (Climent, 2015).

Aunque la coyuntura económica entre 2008 y 2015 tiene una enorme influencia en la evolución del mercado de trabajo, no podemos obviar que en las últimas décadas se han producido cambios económicos y sociales que ayudan a explicar la intensa precarización del mercado laboral y el debilitamiento del paradigma clásico del factor trabajo. Los nuevos procesos productivos, los cambios tecnológicos y la creciente flexibilización del mercado de trabajo, especialmente en España, ha tenido un fuerte impacto en el marco de las relaciones laborales. Las consecuencias han sido la profundización de nuevos ejes de desigualdad social relacionados con un mercado de trabajo cada vez más segmentado y en donde los grupos sociales más vulnerables quedan atrapados en una diabólica alternancia entre trabajos poco cualificados y desempleo que, más pronto que tarde, conduce a la pobreza y la exclusión social. El resultado es una creciente segmentación del Mercado de Trabajo donde 
conviven tres grandes colectivos: un primer grupo de trabajadores "centrales", antes mayoritario, con buenos sueldos y condiciones laborales; un segundo colectivo cada vez más amplio de asalariados y autónomos (generalmente falsos) cuyo vínculo con el mercado de trabajo es cada vez más débil; y un tercer grupo, de evolución creciente, compuesto por trabajadores que actúan al margen del paradigma clásico y que conforman lo que denominamos el trabajo sumergido e informal.

Asimismo, el actual marco económico está generando mayores niveles de pobreza, no sólo por el desempleo, sino también por el progresivo empeoramiento de las condiciones laborales. En este sentido, las grietas del estado del bienestar y el incremento de la pobreza (Beck, 2002; Esping-Andersen, 2000) de los últimos años está afectando prácticamente a todos los ámbitos de la estructura de nuestra sociedad. La precarización estructural de las condiciones laborales, la devaluación salarial y la disolución del vínculo con el mundo del trabajo lleva aparejado un incremento inevitable de la economía informal y de la exclusión social. En este contexto, la dureza de la crisis y las férreas políticas de austeridad sólo contribuyen a tensionar aún más el mercado de trabajo de manera que el porcentaje de trabajadores expuestos a un futuro escenario de trabajo "informal" y pobreza es creciente. Y aunque es evidente que existen una serie de perfiles mucho más vulnerables a la pobreza (migrantes, parados de larga duración y asalariados de baja cualificación), también es cierto que la vulnerabilidad social se está extendiendo rápidamente hacia nuevos espacios socioeconómicos considerados históricamente como de clase media, donde irrumpen nuevos perfiles de riesgo de pobreza. Es decir, personas que han perdido el trabajo, hogares que han visto una reducción sustancial de sus ingresos salariales o familias con dificultades crecientes para pagar sus deudas. En otras palabras, la desaparición gradual del empleo de calidad, como base del concepto de ciudadanía social (Rifkin, 1996; Beck, 2000), está socavando de manera irreversible el gran pacto social suscrito con posterioridad a la Segunda Guerra Mundial y el paradigma clásico del trabajo propio de la sociedad capitalista pos-industrial.

\subsection{Sobre los otros trabajos y los otros trabajadores}

El concepto trabajo no tiene un significado diáfano como parece a primera vista. Es una noción central dentro de las diversas disciplinas sociales y, además, explica una parte importante de nuestras vidas. Más bien, lo podemos definir como una idea conceptual que plantea dificultades a la hora de alcanzar consensos entre los científicos sociales (McGovern, 2013) y es fuente de revisiones teóricas (Noguera Ferrer, 1998) y de numerosos estudios económicos, sociológicos y filosóficos (Arendt, 2009). Y aunque existen muchas explicaciones que interpretan el trabajo como un elemento propio del modelo hegemónico, el elevado economicismo de las ciencias sociales dificulta el análisis de las "otras formas de trabajo". De hecho, la disciplina económica ha construido un discurso que establece lo económico como estructurante y el mercado como mecanismo regulador por excelencia (Misas, 1993). Durante décadas, el pensamiento económico ha alimentado el modelo hegemónico de trabajo con una idea muy sencilla. No existe nada fuera del mercado que no sea pobreza, estableciendo una clara correlación entre la suficiencia económica y el acceso al mercado de trabajo. E incluso el marxismo, que admite la existencia de otras formas de trabajo, eleva el trabajo asalariado a categoría ideológica y política y lo resalta como grupo social al cual representar (Mingione, 1994).

La principal referencia teórica para el análisis de los "otros trabajos" y "los otros trabajadores" proviene de los estudios sobre la informalidad y constituyen el aparato teórico y político más extendido por el neoliberalismo para entender, explicar y dar soluciones a los “otros trabajos” (de la Garza Toledo, 2011).

El concepto de informalidad, construido a partir de las aportaciones de Keith Hart (1973) sobre el mercado laboral de Ghana y las misiones de la OIT en 1974 sobre el empleo en Kenia, surgió a partir de la necesidad de explicar las características de una estructura laboral que no coincidía con los esquemas tradicionales estudiados por los economistas del momento. $\mathrm{Y}$ aunque sus autores iniciales no relacionaron las actividades informales con hechos negativos, la informalidad es un concepto que generalmente ha estado relacionado con el binomio pobreza-trabajo (Chen, 2012). 
El concepto de trabajo informal no es explicativo, es altamente heterogéneo, y puede tener una carga negativa sobre el trabajador, puesto que pone de manifiesto fenómenos particulares no tratados por las líneas teóricas que se centran en el modelo hegemónico de trabajo.

Una de las características del trabajo informal es que se trata de un fenómeno fundamentalmente urbano (Sassen, 1988) y es un concepto clave en la terminología de los organismos internacionales que lo relacionan con temáticas cercanas a condiciones de vida y de trabajo (OIT, BM, FMI, ONU). Asimismo, el trabajo in formal es un indicador de desigualdad, en el sentido que puede ser una actividad de soporte para la reproducción de otras actividades económicas, como es el caso del trabajo femenino dentro del hogar pero, a la vez, es un modelo funcional. En primer lugar, porque absorbe mano de obra cuando no hay suficiente empleo y las condiciones estructurales no permiten buenas condiciones de trabajo y, en segundo lugar, porque es fuente de mano de obra barata. Y puede serlo directamente, a través de todas aquellas actividades que evitan las características propias del trabajo asalariado, pero desarrollan un cometido similar (hostelería, construcción, etc...). O puede serlo indirectamente, a través de todas aquellas tareas que pueden relacionarse con el auto-empleo (verdadero o falso), como pueden ser los chatarreros, los vendedores callejeros, el empleo doméstico, etc...(Chant \& Pedwell, 2008).

Por otra parte, existe un amplio abanico de concepciones sobre la informalidad. Algunas privilegian el análisis de la economía informal, como si esta tuviese una estructura diferente a las formas productivas de la economía formal, mientras que otras tienen como eje de análisis el trabajo informal que reúne a todas las empresas y trabajadores que no cumplen los requisitos legales. Rolando Lazarte (2000), insiste en la descripción de Dagmar Raczynzky sobre los tres enfoques del sector informal. El primero, hace referencia al aparato productivo, que podemos definir como un grupo de unidades productivas de reducidas dimensiones, baja tecnología, ausencia de racionalidad económica y primacía de relaciones personales y familiares sobre las laborales. El segundo, cita el tipo de ocupación donde se definen las principales características de ingreso en el mercado de trabajo informal (fácil acceso, bajos niveles educativos y bajo nivel de renta) y que afecta a la población que no puede acceder a los trabajos formales. Y en el tercero, se encuentran las actividades económicas de baja rentabilidad que, generalmente, sólo pueden sobrevivir a partir del trabajo informal. En cambio, para Cimolli, Primi y Pugno (2006, pág. 91) el sector informal es la respuesta a la excesiva reglamentación y burocracia que existe por parte del Estado para ejercer determinadas actividades productivas y, en la misma línea, de Soto, Ghersi y Ghibellini (1987) afirma que la mejor forma de eliminar la informalidad consiste en disminuir las barreras reglamentarias.

Así pues, la informalidad puede ser interpretada desde diversas perspectivas (Lazarte, 2000). Para la OIT (2002), es un modelo de baja inversión de capital, escasas barreras de acceso y baja utilización de conocimientos y tecnología. En cambio, para las perspectivas más cercana al neoliberalismo la informalidad es un fenómeno creado por el Estado, producto de la regulación de actividades y relaciones laborales que entorpecen el natural funcionamiento del mercado (de Soto et al., 1987). Mientras que para la perspectiva estructural el sector informal es, sobre todo, un modelo de trabajo básicamente de bajo costo (Portes \& Zhou, 1996; Cimolli et al., 2006).

Sin lugar a dudas la informalidad ha jugado un papel fundamental para interpretar y buscar soluciones a todos aquellos trabajos que no entran dentro del marco institucional. Sin embargo, es necesario tener en cuenta al menos tres ejes de análisis a la hora de hablar de informalidad: lo académico, lo político y lo cíclico. Pensar en las diferentes asociaciones sobre lo que es informal, nos puede llevar a una amplia discusión de las variables que determinan qué es y qué no es formal o informal (Shapland \& Heyes, 2017). Asimismo, la informalidad ejerce como regulador de los mercados de trabajo que no tienen un formato adecuado (de la Garza Toledo, 2011) y cuya repercusión es cada vez más global (Hilbrandt \& Richter, 2015; Williams, 2013). Y por último, discutir sobre la función cíclica del concepto nos lleva a pensar en su utilidad en las épocas de expansión económica y en los momentos de crisis (Siqueira, 2016). Un ejemplo de esta realidad sucedeactualmente en las grandes ciudades del norte global, donde la preocupación por las crecientes poblaciones no articuladas ya ha entrado a formar parte de los colectivos organizados alrededor de los derechos de ciudadanía, trabajo y reconocimiento institucional (Espinosa, 2017; Pradel-Miquel, 2016; Sariento, Tilly, de la Garza Toledo \& Gayosso Ramírez, 2016). No obstante, donde se observa un mayor aumento de producción científica sobre trabajo informal, alejado de labibliografía clásica asociadaal "subdesarrollo" (Pfau-Effinger, 2017) o al campo de la criminología (Edelbache, Kratcoski \& Dobovsek, 2016; Ponsaers, Shapland \& Williams, 2008), es en estudios sobre casos específicos de 
grandes ciudades de países "desarrollados", como pueden ser las investigaciones sobre vendedores ambulantes en ciudades como Nueva York, Los Ángeles o Bruselas (Hondagneu-Sotelo \& Estrada, 2011; Basinski, 2014; Voiculescu, 2014), o los estudios sobre chatarreros en Canadá y en Europa (Wittmer \& Parizeau, 2018; Scheinberg et al., 2016).

\section{El caso de España}

En España, la idea de trabajo hegemónico ha ido diluyéndose a medida que las diversas crisis (1993-1995 y 20082015) han facilitado la aprobación de marcos legales destinados a flexibilizar y precarizar el Mercado de Trabajo. En este contexto, existe un elemento que destaca especialmente cuando comparamos España con otros países vecinos. El desempleo no sólo es mucho mayor que la media europea sino que, además, tiene unos efectos diferenciales sobre determinados colectivos como los jóvenes, con una tasa de desempleo que supera el 50\% y con una temporalidad que alcanza el 55\% (EPA 4T. 2017). Esto pone de manifiesto, que la transición laboral, especialmente la de los jóvenes españoles, tras el cambio de paradigma socio-económico y la crisis del Estado del Bienestar, está siendo mucho más intensa que en otros países de nuestro entorno. De modo, que la inestabilidad laboral está cuestionando pilares básicos de estabilidad social como: la incertidumbre en la planificación a largo plazo de proyectos de vida, la creciente dificultad de una carrera profesional u ocupacional acorde con la formación y, en última instancia, la pérdida de derechos laborales y ciudadanos. La globalización y la liberalización de los mercados han incidido significativamente en las formas de organizar el trabajo. Frente a la racionalidad del modelo keynesiano-fordista, en la que el trabajo asalariado constituía un mecanismo de integración ciudadana y de estabilización biográfica, la nueva lógica mercantil ha priorizado la competitividad del mercado, contribuyendo de esta forma a la segmentación, la fragmentación y la individualización del mundo del trabajo (Subirats, 2015). La adaptabilidad a los ciclos productivos y la progresiva desregulación del empleo caracterizan ahora la gestión de la mano de obra en un contexto marcado por las fluctuaciones económicas y por la flexibilización del factor trabajo caracterizado por la inseguridad y la inestabilidad, propia de un capitalismo muy competitivo que exige una mayor responsabilidad del individuo en su participación en el mercado.

Estos datos confirman la enorme influencia que la crisis y la evolución del mercado de trabajo está teniendo sobre el conjunto de la población. Las consecuencias son evidentes y se materializan en la profundización de nuevos ejes de desigualdad social relacionados con un mercado de trabajo cada vez más segmentado, donde los grupos sociales más vulnerables quedan atrapados en una diabólica alternancia entre trabajos poco cualificados y desempleo. El resultado es una creciente segmentación del Mercado de Trabajo donde convive un grupo de trabajadores "centrales", antes mayoritario y ahora cada vez más reducido, y un colectivo cada vez más amplio de asalariados y de "falsos" autónomos con un vínculo cada vez más débil con el mundo del trabajo.

En este contexto de crisis y precarización, donde el trabajo formal está dejando de ser el instrumento de redistribución de riqueza por excelencia, el trabajo informal ha ido ganando peso dentro de la estructura económica española. En España, si sé es extranjero y se desea obtener un permiso de residencia es necesario acreditar que se tiene trabajo. Existen dos vías: ser empleado y que el empleador acredite que tiene una empresa que puede contratar; o bien tener un trabajo por cuenta propia y poder acreditarlo. En ambas situaciones el Estado español define como trabajo las actividades con reconocimiento social, cercanas al modelo hegemónico. Si por ejemplo, un chatarrero solicita a un consulado español un permiso de residencia y aduce que se dedica a recuperar materiales reutilizables o reciclables, lo más probable es que le nieguen el permiso debido a que esta actividad no es considerada un trabajo, y menos un trabajo formal y deseable.

La ciudad de Barcelona, con un PIB de 76,604.8 millones de euros en 2016, según fuentes del Ayuntamiento de Barcelona, representa aproximadamente un $6 \%$ del total de la economía española y cuenta con una tasa de desempleo del 11.5\% (EPA $4^{\circ}$ T. 2016). La mayor parte del empleo en la ciudad se da en el sector servicios (76.2\%) y de éste, algo más del 50\% son actividades asociadas a la industria turística de la ciudad (comercio, reparaciones, hotelería, actividades financieras, inmobiliarias, administrativas y servicios auxiliares, actividades deportivas y culturales y otros). Junto a estas actividades laborales reguladas, muchas de ellas bastante precarias, existen otras que no entran dentro del marco hegemónico de trabajo y que están asociadas directa o indirectamente con el turismo. 
Entre éstas, las más visibles son: la venta ambulante, chatarreros, músicos de calle y metro, estatuas humanas, vendedores de latas de cerveza, masajistas de playa, bici-taxistas, pintores, etc... No hay muchos datos sobre los trabajos informales en Barcelona o en España pero, en general, son actividades que no están dentro del conocimiento público o que sistemáticamente se ocultan en las entrañas de la economía sumergida. Y aunque la información que se tiene sobre el trabajo en la ciudad no dice mucho sobre los trabajadores que se hayan fuera de los marcos hegemónicos, sí existen indicios de que es un fenómeno que sobrepasa las connotaciones de los grupos de trabajos marginales y que tiene características de ciudad relacionadas con una de sus principales actividades; el turismo.

Sobre los otros trabajos en Barcelona, existe una larga historia no escrita, o por lo menos, no divulgada. Los inicios de la actividad de los chatarreros pueden rastrearse desde el siglo XVIII, y en esa época su denominación es la de traperos, mientras que la venta ambulante existe desde el siglo XIII y su principal punto comercial es el Mercado de Belcaire, hoy atracción turística de la ciudad. No obstante, es una historia donde la ciudad regula y penaliza constantemente nuevas y viejas actividades y convierte en "otros trabajos" actividades históricamente reconocidas que, en muchas ocasiones, acaban desplazando y desarticulando a los trabajadores que las desarrollan. Esta estigmatización, que penaliza el trabajo informal, contribuye a consumar la idea de que existe una forma excluyente de reconocer el trabajo y de gestionar todas aquellas actividades que están fuera del ámbito hegemónico del trabajo formal.

\section{Un estudio de caso: Los chatarreros sub-saharianos en la ciudad de Barcelona}

En Barcelona los chatarreros, son hombres y mujeres que trabajan en las calles, buscando materiales y objetos a los cuales restituirle una parte de su valor perdido. Y aunque su nombre está relacionado con los objetos que recolectan, la denominación que mejor puede describir su actividad es la de recuperadores. Pueden ser definidos como mineros de ciudad que extraen materiales reciclables y objetos de re-uso entre los residuos sólidos urbanos, aunque se diferencian de los mismos porque ni son considerados trabajadores y ni se les reconoce el valor que agregan a los materiales. En otras palabras, el cobre en las manos del minero es materia prima, mientras que el cobre en manos del chatarrero es parte de los deshechos de la ciudad, evidenciando el significado social de su trabajo y la relación con los objetos que los rodean (Appadurai, 1991).

En muchas ocasiones los chatarreros no tienen reconocimiento social ni siquiera para ser considerados trabajadores. Son tratados como un problema social, como una actividad espontánea de supervivencia, como un desempeño para personas en condiciones de indigencia o, en el peor de los casos, una actividad asociada a la delincuencia. Cargan con muchos estigmas: pobres, indocumentados, inmigrantes, desempleados, marginales, precarios, desorganizados, sucios, etc. Y muchas de estas "huellas" sociales proceden de la ignorancia, ocultamiento e invisibilización de las comunidades que llevan a cabo esta actividad económica, y muy especialmente, de la lógica de su trabajo y de los mecanismos y estrategias que lo reproducen.

Respecto la actividad, ésta se enmarca dentro de una ocupación laboral que podríamos definir como reciclaje informal. Reciclaje, porque participa de una lógica económica y empresarial que busca reciclar o dar un nuevo uso a los materiales que recuperan los chatarreros, e informal, porque está poco o nada intervenida por la acción estatal, con todas las consecuencias que ello acarrea.

El reciclaje informal llevado a cabo por los chatarreros es un tipo de trabajo precario de características globales. En la mayoría de las grandes ciudades los chatarreros se dedican a seleccionar, separar, transportar y vender materiales reciclables y artículos de re-uso de la basura (Samson, 2009). Muchas personas se dedican a esta actividad en las grandes áreas urbanas y, tan sólo, en años recientes ha sido regulada en algunas ciudades del mundo, llevando a cabo procesos de gestión de los residuos con separación en la fuente. No obstante, se puede afirmar que existen diferencias en como se presenta esta práctica en economías centrales o periféricas. Principalmente, por las lógicas de los mercados, por el valor social que tiene este tipo de trabajo, por su asociación a fenómenos de migración internacional y exclusión social y por las actividades económicas prioritarias de cada ciudad. 
El caso de Barcelona, parte de un contexto marcado por la crisis económica, el alto desempleo y la fuerte migración internacional y se fundamenta en grupos sin acceso al mercado de trabajo que crean estructuras organizativas informales alrededor de esta actividad. Respecto la población que se dedica a la recolección de materiales, no existen datos fiables y tan sólo se pueden hacer contextualizaciones amplias de carácter general. A grandes rasgos, se trata de una población mayoritariamente migrante (en este caso de origen subsahariano) que dispone de una infraestructura (una nave industrial y bodegas "ocupadas") para llevar a cabo su actividad laboral (Mendoza, 2014).

Históricamente, el trabajo de los chatarreros en Barcelona ha estado asociado a diferentes colectivos. Su origen se sitúa en el siglo XVIII y está circunscrito a la recuperación de trapos. Con posterioridad a la Primera guerra mundial, y como consecuencia de la escasez, tiende a la diversificación de materiales y acerca el oficio al propio del vendedor de objetos de segunda mano. A partir de la Segunda República, el oficio se regula y se negocian las condiciones de trabajo con el Sindicat de drapaires de Barcelona (Sindicato de Traperos de Barcelona) y una vez finaliza la Guerra Civil, el papel de los traperos cobra una cierta importancia social por el trabajo de recuperación de materiales y objetos tras la destrucción de la ciudad (Fernandez Valentí). Más recientemente, con el fuerte repunte de la inmigración a partir del siglo XXI, este oficio, que tradicionalmente había estado asociado a colectivos gitanos, pasa a ser desarrollado por migrantes de Europa del este y, sobre todo, por personas de origen sub-sahariano que son los que forman el colectivo de referencia de esta investigación.

Las principales características del universo investigado, según la información aportada por los propios chatarreros, la prensa y unos pocos documentos legales (Desahucio por precario, $2013 \mathrm{sec}$. C; Síndic de Greuges de Catalunya, 2014), describe que el número de personas que trabajan en torno a la nave de la calle Puigcerdá es de alrededor de 700, de los cuales 300 viven en la misma y a la cual se suman los otros grupos de chatarreros que acuden de otras bodegas cercanas o de otras partes de la ciudad. La mayoría son de origen senegalés, aunque su comprobación es compleja puesto que muchos de ellos no tienen permiso de residencia y no declaran su nacionalidad de origen como una estrategia migratoria para evitar su repatriación. Con relación al género, solo se pudo comprobar que existe una baja presencia femenina y que, por lo tanto, se trata de una población masculina, sin familia y sin posibilidad de incorporarse al mercado de trabajo asalariado.

\subsection{El trabajo de los chatarreros sub-saharianos}

El trabajo de los chatarreros en Barcelona se basa en un grupo de actividades con división de funciones y conocimientos para seleccionar, separar, transportar, mejorar y vender materiales reciclables y objetos de re-uso. Es una actividad urbana global íntimamente relacionada con la lógica del alto consumo y la producción de residuos (Samson, 2009).

En la nave industrial ocupada de la calle Puigcerdà del barrio de Poblenou el movimiento es constante. En un día cualquiera pueden verse diversos grupos de chatarreros que se dedican a llenar un contenedor, posiblemente suministrado por una empresa que compra este producto y que luego lo vende a la industria $\mathrm{Y}$ otros muchos que colaboran en el pesaje de materiales que se lleva a cabo en los diversos negocios distribuidos a lo largo de la nave industrial y que compran casi todos los materiales suministrados por los recogedores de chatarra.

El oficio del chatarrero es una actividad que combina un uso intensivo de la mano de obra y un ambiente laboral en el que el azar juega un papel fundamental. Las fuentes de materiales, los horarios de recogida de muebles y trastos, las condiciones climáticas o la zona de la ciudad que cada chatarrero tiene asignada, son variables que determinan el recorrido diario y el jornal. Así mismo, las estrategias de los distintos chatarreros pueden variar en función de los lugares de rastreo y de los horarios que cada uno tenga asignado. La actividad de recolección se basa en una búsqueda constante "de fuente a fuente". Es decir, entre contenedores, edificios en obras o lugares donde se acumulan los trastos. Por lo tanto, se trata de una actividad que no es lineal y que incluye acercarse a las fuentes y observar,preguntar y, si es necesario, esperar. La Figura 1 muestra un recorrido típico de los chatarreros de la nave de Puigcerdà. 


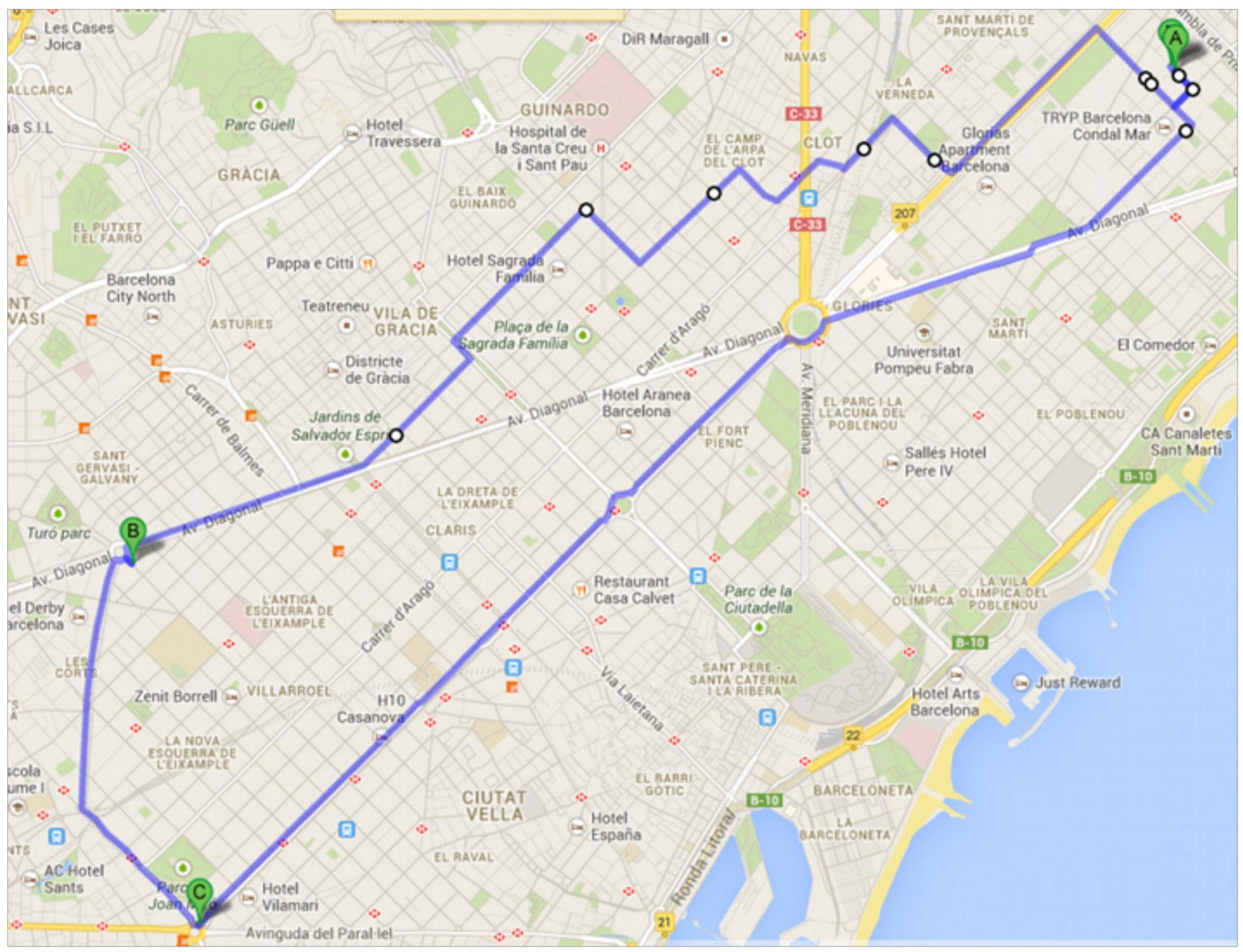

Figura 1. Fuente: Google Maps

Eso depende, un dia puedes salir y caminar de 7 a 7 (7-19b) y no pillar nada, algún día puedes salir y conseguir 100 euros, eso es cosa de suerte, nadie te puede decir (que) vas a conseguir, si por ejemplo, hoy voy a encontrar eso, eso, o eso. Lo que pasa, yo salgo de mi casa, no (se) sabe nada, (ni) si un coche va a matarme, pero cada día busco y encuentro. Si llego a mi casa voy a decir gracias a Dios, estoy en casa, porque es muy difícil. (entrevista $\mathrm{n}^{\circ} 4$ )

Por otra parte, los chatarreros entrevistados, expresan que la actividad no permite el ahorro, ni ningún excedente para poder enviar dinero a sus familias. Lo que ganan diariamente alcanza para la reproducción simple de su forma de trabajo: alojamiento, comida y transporte.

Lo único que piensas es mira si me voy a la calle cojo el carro y ando y lo que me encuentre y lo puedo vender el mismo día y te pagan, con eso puedo seguir haciendo la vida. (entrevista $\mathrm{n}^{\circ} 4$ )

Esta situación, según explican, se ha acentuado desde la crisis, ya que hay menor producción de residuos y mayor competencia, puesto que muchos subsaharianos que antes trabajaban en la construcción ahora se "autoemplean" en el "reciclaje informal".

Con nuestro trabajo no ganamos nada, se gana algo para pagar la habitación, comer y ya está (...) ahora no (enviar dinero a familiares), porque ahora no hay trabajo (materiales en la calle), antes sí. (entrevista $\mathrm{n}^{\circ} 7$ )

En cierto momento mucha gente ganaba un poco de dinero y lo podía mandar a su familia. Dos años atrás, podías llegar a final de mes y sacar 700 o 800 euros, pero actualmente lo que uno gana (ya) no llega para tener eso. (entrevista $\mathrm{n}^{\circ} 5$ )

\subsection{La construcción social de la actividad}

La construcción de solidaridad y respaldo es relativamente sólida entre los chatarreros y, aunque difiere según el colectivo analizado, muestra una elevada cohesión interna. 
(La relación con los otros chatarreros) es de amistad, de hermandad, de trabajo, de colega, compatriota, de todo esto, porque aqui no tenemos nuestros padres, y normalmente no venimos con nuestros hermanos de sangre, venimos solos, y al vivir la mismas condiciones nos convierte en gente de la misma clase, y esto crea algo, es muy fuerte, aquí tú no puedes tocar un africano y salirte con la tuya. (entrevista $\mathrm{n}^{\circ} 1$ )

Asimismo, la relación que establecen con el entorno social es generalmente buena. Es muy representativo el respaldo que los chatarreros obtuvieron dela asociación de vecinos del barrio de Poblenou en contra del proceso legal de desalojo de la nave de Puigcerdà (Desahucio por precario, $2013 \mathrm{sec}$. C). Lo mismo sucede con los chatarreros de Bogatell. Y aunque existen casos de racismo, los chatarreros los asocian con hechos totalmente aislados.

(La relación con los de fuera de la nave) es muy buena, los vecinos siempre nos han tratado bien, hay un grupillo de gente que no les gustamos para nada, eso se debe entender, aqui no sé si hay 27 mil o 30 mil babitantes, si son 10 que nos enseñan su rechazo, respetamos, pero no nos impide que nosotros sigamos nuestro camino. (entrevista $\mathrm{n}^{\circ} 1$ )

Otro de los actores necesarios para entender el funcionamiento de la actividad es el intermediario. Se trata del eslabón que permite la conexión de esta ocupación informal con los procesos industriales formales de reciclaje y su función es comprar, separar y acumular los materiales. Con estas personas, los chatarreros establecen una relación de cooperación, pero también de confianza y de relativa dependencia. En la mayor parte de los casos, el intermediario es una pequeña empresa que dispone de almacén y que compra diversos tipos de materiales. Asimismo, es un agente que actúa como enlace entre las empresas de reciclaje y los chatarreros, aunque lo hace desde una posición dominante que lo convierte en un facilitador del trabajo pero que, al mismo tiempo, puede ocultarla relación entre capital y trabajo, en la que subyacen formas de explotación, corrupción o procesos de acumulación (Stovel \& Shaw, 2012). El intermediario, por lo tanto,juega este doble rol de confianza y dependencia, configurando la mayor parte de las veces una posición oligopólica en la que el chatarrero no "tiene" más opción que venderle su material.

La chatarra la pesan bien, (...) yo tengo clientes fijos ellos me conocen, yo los conozco, pienso que ellos no me van a engañar.El (cobre) de primera a 4.80, a 4.50, a 4.40 (euros), depende de la persona que lo compra. (...)Puedes vender a otro precio, pero (tienes) que vender a ellos. (entrevista $\mathrm{n}^{\circ} 6$ )

La construcción social del trabajo del chatarrero y de las personas que desempeñan esta ocupación es socialmente negativa. Tanto su proyección externa en los medios de comunicación como la percepción social que tienen de sí mismos, no ayuda a reconocer su actividad como un trabajo "normalizado". Más bien lo contrario, es percibida socialmente como una ocupación circunstancial con la que no es posible crear elementos de identificación. Y aunque sea una actividad de características físicas y manuales, desde un punto de vista social, es contemplada como un estigma de deshonra, vergüenza y pérdida de respeto.

Yo no quería (andar por la calle con el carro) porque tenía vergüenza, mi compañero me dice es como un trabajo como el que más, lo que pasa es que tú no tienes que mirar a nadie, tienes que mirar por ti. (entrevista $\mathrm{n}^{\circ} 3$ )

En última instancia, existe una idea constante sobre este tipo de trabajo: "ésta es una situación transitoria". Y aunque es un trabajo con características comparables a muchos otros, éste se identifica como una actividad necesaria para la supervivencia y la reproducción simple y no como la propia de un trabajo transformador (Arendt, 2009). Esta realidad,nos permite entender lo perverso que es el modelo interpretativo del mercado de trabajo que se perfila como un escenario donde sólo pueden participar aquellos que son reconocidos social y económicamente.

\subsection{E1 reconocimiento social de la actividad}

Desde una perspectiva de oferta y demanda, la ocupación de los chatarreros se puede considerar como la de un proveedor de materia prima para determinadas tareas productivas. En cambio, si se pone el foco en la función social de la actividad, se observan diferencias fundamentales. El programa de separación y recolección de residuos sólidos del Ayuntamiento de Barcelona fomenta la separación de materiales en la fuente (en los 
contenedores, en la calle, en las obras...) y luego son las empresas prestadoras del servicio las que gestionan el procesamiento de los residuos. Esto implica que el trabajo de los chatarreros pueda ser considerado como un sobre-trabajo donde la recolección de materiales forma parte de una estrategia de subsistencia en el marco de una economía con alto desempleo. Por lo tanto, se puede deducir que este trabajo es intensivo en mano de obra y, a la vez improductivo, puesto que es un trabajo que se superpone a la actividad de las empresas contratadas por el ayuntamiento. Sin embargo,es innegable la existencia en la ciudad de un espacio económico de manejo de residuos que parte de los chatarreros. Esto se debe, fundamentalmente, a que la actividad de éstos (proveedor de materias primas) se complementa con dos funciones paralelas: recuperar el valor de cambio y de uso de determinados objetos y disminuir los costes de compra de algunos bienes necesarios para una parte de la población con muy pocos recursos económicos. Sin embargo, en ninguno de los dos casos se considera una actividad productiva, aunque se trate de actividades inherentes al sistema capitalista.

Pero sin lugar a dudas, la interpretación que más determina su actividad es la idea de la emergencia social, ya que por medio de ésta se ocultan las múltiples facetas de su trabajo. En lugar de reconocer su actividad, el Ayuntamiento, los vecinos o los medios de comunicación solo saben reclamar medidas asistenciales sin entender que esta acción invisibilizaba cualquier otra faceta laboral de los chatarreros y que refuerza la imagen de una actividad económica de supervivencia. Además, esta percepción se contrapone a la idea que tienen los chatarreros sobre su función social, donde se recalca su potencial de trabajador y la necesidad de independencia económica por medio del trabajo.

\subsection{El capital como forma de representación del trabajo}

Existen dos maneras de ocultamiento del trabajo: la concreta y la abstracta. La concreta es la que se ha venido discutiendo hasta ahora y, básicamente, se refiere a las formas de no reconocimiento social de la actividad, mientras que la abstracta se presenta de una manera más sutil. Es una forma de ocultamiento que se refiere al no reconocimiento del capital como expresión de la materialización del trabajo.

El capital es el modo en como se expresa el excedente del trabajo. Es el valor creado por una actividad económica que, a través de un proceso de acumulación, sirve para reproducir las condiciones iniciales de la misma. Como indica Hernando de Soto et al. (1987), en su amplia investigación sobre la informalidad en Perú, el capital necesita de un respaldo institucional y de un reconocimiento por parte del Estado. Su investigación expone como los largos procesos burocráticos -legales e ilegales- generan espacios de vida económica que están fuera de la regulación del Estado y sin esta legalización, el capital carece de valor (de Soto et al., 1987; Hart, 2000).

Está claro que el capital tiene que tener un respaldo institucional, y dicho apoyo es, en última instancia, una forma de reconocimiento del trabajo necesario para poder acumularlo. En el caso de los chatarreros subsaharianos en Barcelona parece evidente la ausencia de respaldo a los capitales que éstos han construido.

Existe toda una discusión sobre si las pequeñas unidades productivas cumplen los requisitos para ser denominadas capitalistas. Es decir, que su lógica sea la de acumular capital. En algunas interpretaciones sobre el auto-empleo y la pequeña empresa, se afirma que éstas pueden ser consideradas un tipo de trabajo externalizado donde se borra la relación entre capital y trabajo, de manera que estas actividades no concentrarían capital, puesto que quien lo concentra son las empresas de mayor dimensión para las cuales trabajan. Con relación a los chatarreros, es innegable que existen unas condiciones necesarias para poder reproducir la actividad. Y aunque no se pueda afirmar que juegan el rol de acumuladores capitalistas, la necesidad de invertir en unos bienes determinados para llevar a cabo la actividad, se puede interpretar como el capital necesario.

En el caso de los chatarreros, existen dos ejemplos sobre la ausencia de respaldo institucional a la hora de acumular. El primero, es el evidenciado tras el desalojo de la nave de Puigcerdà (2013). Los chatarreros puede que estuviesen utilizando en forma ilegítima la nave, y se puede considerar que su uso como medio de producción pueda ser cuestionable desde una perspectiva legal. Sin embargo, es evidente que todo el capital que los chatarreros acumularon allí era legítimamente de ellos y que no fueron reconocidos los materiales acumulados, el acondicionamiento de la nave para la producción, las estructuras sociales de producción ni 
tampoco el "know-how" acumulado en la infraestructura donde vendían los materiales reciclables y los objetos de re-uso. Las medidas adoptadas en el desalojo no salvaguardaron el capital de los chatarreros, a diferencia de lo que ocurre con determinados sectores del mercado tradicional, donde el Estado, en aras del bien común, trata de salvaguardar el capital acumulado (como sucedió en España con el rescate bancario en plena crisis económica). Con los chatarreros no fue así, como lo explica uno de sus portavoces en una rueda de prensa ofrecida días después del desalojo:

Tenemos muchas cosas que han quedado en la nave, han sido dos años de lucha, dos años recogiendo cosas, estamos juntando cosas, la mitad de estas cosas quedaron en la nave, estas cosas son nuestras cosas, y ahora están derrumbando la nave encima de nuestras cosas, entonces estas cosas el Ayuntamiento tiene que indemnizar de alguna manera, de esa gente que ba estado trabajando casi 2 años. (entrevista n. ${ }^{\circ}$ )

En este caso, el no reconocimiento institucional del capital lleva la reproducción de la actividad laboral a una forma menor que simple. Es decir, los elementos para llevar a cabo dicha actividad no alcanzan a ser repuestos por el trabajo realizado. Y como referencian muchos estudios sobre la informalidad, en sus versiones más precarias, puede llevar a formas de trabajo en las que no se diferencian los ingresos de los salarios y de las ganancias. De manera, que al final de periodos prolongados se aprecia que los trabajadores no pagan la totalidad de su trabajo, no obtienen ninguna rentabilidad y, por lo tanto, están consumiendo lentamente el capital invertido (Alba Vega \& Kruijt, 1995).

\subsection{Los chatarreros, los otros trabajadores (La relación entre sujeto y trabajo)}

Bajo un contexto de crisis económica, parece lógico que surjan problemáticas estructurales que con anterioridad no siempre hayan sido perceptibles. En todas las sociedades capitalistas existen actividades laborales y económicas que no forman parte de las estructuras dominantes del mercado de trabajo y que se magnifican en épocas de crisis. Los trabajos informales no son nuevos, son cíclicos y denotan la existencia de una población muy precaria que no tiene siquiera el reconocimiento de su trabajo. Como ya se ha expuesto a lo largo de este artículo, esta realidad tiene dos interpretaciones complementarias, una cercana a la lógica económica y otra a la lógica del control social.

Por una parte, la actividad de los chatarreros es funcional a la lógica del mercado y es una fuente de trabajo barato en actividades de alta intensidad en mano de obra. Pero, por otra parte, los chatarreros son una población que lleva a cabo un trabajo improductivo al que deben aplicarse los mecanismos de control social y la lógica de las barreras de acceso a la integración propia de los grupos de inmigrantes (Gálvez, 2017).

Los "otros trabajos" no son actividades particulares, ni formas económicas diferentes a las de su entorno. Pueden ser, sencillamente, ocupaciones importantes en un momento dado, para luego ser consideradas un hacer o un trabajo no reconocido. El caso de los chatarreros es claro, y se puede contrastar con diversos estudios internacionales, (Medina, 2007; Samson, 2009; Scheinberg, Informal Sector Integration and High Performance Recycling: Evidence from 20 Cities, 2012; GAIA, 2012). Además, los "otros trabajos", como lo ejemplifican los diversos estudios de caso, inciden en el panorama político actual, puesto que la transversalidad de sus reclamos superan las clásicas reivindicaciones sindicales. La lucha de los chatarreros en Barcelona son indisolubles a lucha de las asociaciones de vecinos y movimientos sociales en contra de la discriminación. Y, en el mismo sentido, cabe asociar la lucha de los vendedores ambulantes junto con las reivindicaciones vecinales por el libre uso del espacio público y la crítica al modelo turístico de la ciudad.

En igual medida, es indispensable el cruce de variables sociales para entender mejor los "otros trabajos" y los “otros trabajadores". No sólo hace falta entender que el trabajo de los chatarreros está estigmatizado, sino que también es necesario relacionar el tipo de trabajo con los grupos específicos que lo llevan a cabo. Las desigualdades en el mundo del trabajo no sólo están relacionadas con tipos de actividades, sino también con los actores que las desempeñan. Por lo tanto, no solo se trata de actividades que se ocultan, o que son marginales, sino que el fenómeno está íntimamente relacionado con los grupos que las llevan a cabo. El modelo hegemónico no sólo está construido a partir de la idea normativa del trabajo, sino también a partir de quién lo ocupa(hombremujer, joven-adulto, blanco-negro, residente-extranjero, etc...). Y si en el caso del género es evidente, la brecha 
salarial entre el trabajo masculino y femenino en España es aproximadamente del 24\% (UGT, 2015), lo mismo ocurre con relación a la percepción del inmigrante. Sujeto y trabajo forman parte de una misma relación y es necesario entender la correlación existente entre carencia de ingresos, control institucional, racismo y segmentación del mercado de trabajo en la reproducción de la actividad.

\section{Conclusiones}

Desde principios del siglo XXI, se observa un cambio de paradigma del factor trabajo que está muy relacionado con el nuevo contexto económico generado por la globalización económica y por las posteriores consecuencias de la gran crisis económico-financiera del 2008-2015. Uno de los factores que más ha impactado en el deterioro y en la evolución del mercado de trabajo ha sido el incremento del desempleo, la consolidación de la precariedad laboral y el incremento del riesgo de pobreza de amplias capas de las clases trabajadoras, especialmente, en los países del sur de Europa. No obstante, más allá de las cifras, el mundo del trabajo es un espacio restringido donde solo se contabilizan las actividades legales y cuantificables, mientras que los otros trabajos, los "informales", acostumbran a ser invisibles. En general, el mercado de trabajo es un espacio compuesto por un amplio abanico de ocupaciones y actividades llevadas a cabo en el seno de la sociedad pero, a su vez, es un espacio excluyente para actividades ajenas al paradigma dominante (Pahl, 1991).

El concepto de trabajo informal no es explicativo, es altamente heterogéneo y puede tener una carga negativa sobre el trabajador (Chen, 2012). Es un concepto con creciente relevancia académica, fundamentalmente urbano y, al mismo tiempo, es un indicador de desigualdad que se manifiesta en diversos ámbitos laborales, e incluso no laborales, como su relación con las tareas de reproducción del trabajo femenino dentro del hogar. Además, es un modelo funcional que absorbe mano de obra cuando no hay suficiente empleo y que se manifiesta a partir de actividades que evitan las características propias del trabajo asalariado, aún desarrollando un cometido similar (hostelería, construcción, etc...) o a través de tareas que se pueden relacionar con el auto-empleo (verdadero o falso), como es el caso de los chatarreros.

El caso específico de los chatarreros, es un tipo de trabajo precario de características globales. En la mayoría de las grandes ciudades los chatarreros se dedican a seleccionar, separar, transportar y vender materiales reciclables y artículos de re-uso de la basura (Samson, 2009). Muchas personas se dedican a esta actividad en las grandes áreas urbanas y, tan sólo, en años recientes ha sido regulada en algunas ciudades del mundo, llevando a cabo procesos de gestión de los residuos con separación en la fuente. No obstante, existen diferencias en como se presenta esta práctica entre economías centrales o periféricas. Principalmente, por las lógicas de los mercados, por el valor social que tiene este tipo de trabajo, por su asociación a fenómenos de inmigración internacional y de exclusión social y por las actividades económicas de la ciudad.

La construcción social del trabajo del chatarrero y de los grupos a los que se les asocia es uno de los elementos explicativos para interpretar los trabajos informales en contextos como los estudiados. Es necesario entender que el trabajo de los chatarreros se construye socialmente por el tipo de trabajo y por los actores que lo desempeñan. Por lo tanto, no solo se trata de actividades que se ocultan, o que son marginales, sino que el fenómeno está íntimamente relacionado con los grupos que las llevan a cabo. De manera, que el modelo hegemónico no solo está construido a partir de la idea normativa del trabajo, sino también a partir de quién lo ocupa (hombre-mujer, joven-adulto, blanco-negro, residente-extranjero, etc...). Debido a esto, su proyección externa en los medios de comunicación así como la construcción social que hacen de su propio trabajo, no ayuda a reconocer su actividad como un trabajo "normalizado". Más bien lo contrario, es percibida socialmente como una ocupación circunstancial con la que no es posible crear elementos de identificación. Y aunque se trata de una actividad de características físicas y manuales similar a muchos otros trabajos formales, desde un punto de vista social sólo se reconocen las "necesidades humanitarias" asociadas a estos colectivos como única faceta interpretativa y explicativa. Ahora bien, la falta de reconocimiento social de los trabajos informales no explican suficientemente los mecanismos que operan en la ocultación del mismo. En el caso de los chatarreros de Barcelona, uno de los elementos determinantes para entender estos mecanismos de ocultación consiste en la dificultad de construir capital a partir del propio trabajo, y este hecho viene determinado, en gran medida,por la ausencia de respaldo institucional para activar el proceso de acumulación de capital y de reproducción de la actividad laboral. 
Las actuales investigaciones sobre trabajos informales en Europa aún son suficientes para poder extraer conclusiones mucho más amplias, como sucede en las grandes recopilaciones de investigaciones sobre este tipo de trabajo en el continente africano (Kinyanjui, 2014) o en América Latina (de la Garzo Toledo, 2011) y, probablemente, las limitaciones de este artículo están directamente relacionadas con la capacidad comparativa del mismo. Sin embargo, esta realidad parece indicar un camino claro para futuras investigaciones. En particular, sobre aspectos como el reconocimiento social, las formas de gestión del trabajo informal en las grandes ciudades o la construcción social de nuevos modelos de trabajo y su reconocimiento y relación con grupos específicos de población.

\section{Declaración de conflictos de interés}

Los autores no han declarado posibles conflictos de interés por lo que respeta a la investigación, la autoría y/o la publicación de este artículo.

\section{Financiación}

Los autores no recibieron ningún soporte financiero para la investigación, la autoría y/o la publicación de este artículo.

\section{Referencias}

Alba Vega, C., \& Kruijt, D. (1995). La utilidad de lo minúsculo: Informalidad y microempresa en México y los países andinos. México: El Colegio de México.

Appadurai, A. (1991). Introducción: Las mercancias y la política de valor. En A. Appadurai (Ed.), La vida social de las cosas: Perspectiva cultural de las mercancias (págs. 17-88). México: Grijalbo.

Arendt, H. (2009). La condición bumana. Barcelona: Paidós.

Basinski, S. (2014). Hot Dogs, Hipsters, and Xenophobia: Immigrant Street Food Vendors in New York. Social Research, 81(2), 397-408.

Bauman, Z. (2004). Modernidad líquida. Buenos Aires: Fondo de Cultura Económica.

Beck, U. (2000). The Brave New World of Work. Oxford: Polity Press.

Beck, U. (2002). Individualization. Londres: Individualization.

Castells, M. (2000). La era de la información (Vol. 1). Madrid: Alianza Editorial.

Castillo, J.J. (1998). A la busqueda del trabajo perdido. Madrid: Tecnos.

Castillo, J.J., \& de la Garza Toledo, E. (2000). Tratado Latinoamerica de Sociología del Trabajo. Méjico: Fondo de Cultura Económica.

Chant, S., \& Pedwell, C. (2008). Women, gender and the informal economy: An assessment of ILO research and suggested ways forward. Geneva: ILO.

Chen, M. (2012). The Informal Economy: Definitions, Theories and Policies. Cambridge: Wiego.

Cimolli, M., Primi, A., \& Pugno, M. (2006). Un modelo de bajo crecimiento: La informalidad como restricción estructural. Revista de la CEPAL, (88), 89-107.

Climent, V. (2015). La nueva pobreza en el mercado de trabajo. Intangible Capital, 11(2), 270-283.

Credit Suisse (2015). Global Wealth Report 2015. Zurich: Credit Suisse AG.

de la Garza Toledo, E. (2001). Problemas clásicos y actuales de la crisis del trabajo. En E. de la Garza Toledo, \& J. C. Neffa (Ed.), El trabajo del futuro, el futuro del trabajo. Buenos Aires: Clacso.

de la Garza Toledo, E. (2011). Problemas conceptuales, relaciones de trabajo y derechos laborales de los trabajadores informales. Revista Internacional de Estadística y Geografía, 2(3), 5-15. 
de la Garzo Toledo, E. (2011). Trabajo no clásico y acción colectiva (Vol. 1). México DF: Plaza y Valdes.

de Soto, H., Ghersi, E., \& Ghibellini, M. (1987). El otro sendero: la revolución informal. Lima: Oveja Negra.

Denzin, N., \& Lincoln, Y. (2012). Manual de investigación cualitativa. Barcelona: Gedisa.

Desahucio por precario, Juicio verbal 411 (Juzgado Primera Instancia 21 Barcelona 17 de Junio de 2013 sec. C).

Edelbache, M.r., Kratcoski, P.C., \& Dobovsek, B. (Edits.). (2016). Corruption, Fraud, Organized Crime, and the Shadow Economy. Boca Ratón: CRC Press.

Esping-Andersen, G. (2000). Fundamentos sociales de las economías postindustriales. Barcelona: Ariel.

Espinosa, H. (2017). El mercadillo rebelde de Barcelona. Prácticas antidisciplinarias en la ciudad mercancía. Quaderns-e, 1(22), 67-87.

Fernandez Valentí, R. (s.f.). El tranvia 48. Retrieved on May 5 ${ }^{\text {th }}, 2018$ from: eltranvia48.blogspot.com.es

Fernández, L., Pena Pan, J., \& Rey Manzón, P. (2014). WAW: Waste Pickers Around the World Database. WIEGO.

GAIA (2012). On the Road to Zero Waste: Successes and Lessons From Arround the World. GAIA.

Gálvez, J. (March 20 th 2017). Miles de inmigrantes 'encarcelados' para nada. Retrieved on 21 de March 21 ${ }^{\text {st }}, 2017$ from: http://politica.elpais.com/politica/2017/02/03/actualidad/1486132000 254307.html

Hart, K. (1973). Informal Income Opportunities and Urban Employment in Ghana. The Journal of Modern African Estudies, 11(1), 61-89. https://doi.org/10.1017/S0022278X00008089

Hart, K. (2000). The Memory Banck: Money in an Unequal World. Londres: Profile Books.

Hilbrandt, H., \& Richter, A. (2015). Reassembling austerity research. Ephemera, 15(1), 163-180.

Hondagneu-Sotelo, P., \& Estrada, E. (2011). Intersectional Dignities: Latino Immigrant Street Vendor Youth in Los Angeles. Journal of Contemporary Ethnography, 40(1), 102-131. https://doi.org/10.1177/0891241610387926

Kinyanjui, M.N. (2014). Women and the informal economy in urban Africa: From the margins to the centre. London: Zed Books.

Lazarte, R. (2000). El "sector informal" una revisión conceptual bibliográfica. (IIEc-UNAM, Ed.) Problemas del desarrollo, 31(121), 35-62.

McGovern, P. (2013). Contradictions at Work: A Critical Review. Sociology, 48(1), 1-18.

Medina, M. (2007). The World's Scavengers: Salving for Sustainable consuption and production. Lanham: Altamira Press.

Mendoza, I. (2014). Afrikalando in the gueto: Prácticas de reciclaje urbano en Barcelona. Tesis Máster, Universidad de Barcelona, Máster enAntropología i etnografía.

Miguélez, F., \& Torns, T. (1998). Introducción al análisis del trabajo y de la vida cotidiana. Papers, 55, 9-25. https://doi.org/10.5565/rev/papers.1930

Mingione, E. (1994). Las Sociedades Fragmentadas: Una Sociología de la Vida Económica Más Allá Del Paradigma Del Mercado. Madrid: Ministerio de Trabajo y Seguridad Social.

Misas, G. (1993). Desarrollo científico y teoría económica: nuevos retos para la enseñanza de la economía. Cuadernos de Economía, 13.

Noguera Ferrer, J.A. (1998). La transformación del concepto de trabajo en la teoría social (la aportación de las tradiciones marxistas). Barcelona: Universidad Autonoma de Barcelona.

OIT (2002). El trabajo decente y la economia informal. Ginebra: OIT.

Pahl, R. (1991). Divisiones del trabajo. Madrid: Ministerio de Trabajo y Seguridad Social.

Pfau-Effinger, B. (2017). Informal employment in the poor European periphery. International Journal of Sociology, 37(7-8), 387-399. https://doi.org/10.1108/IJSSP-07-2016-0080 
Polanyi, K. (1989). La Gran transformación: crítica del liberalismo económico. Madrid: La Piqueta.

Ponsaers, P., Shapland, J., \& Williams, C.C. (2008). Does the informal economy link to organised crime? International Journal of Social Economics, 35(9), 644-650. https://doi.org/10.1108/03068290810896262

Portes, A., \& Sassen, S. (1987). Making it Underground: Comparative Material in Informal Sectorin Western Market Economies. American Journal of Sociology, 93(1), 30-61. https://doi.org/10.1086/228705

Portes, A., \& Zhou, M. (1996). Self-Employment and the Earnings of Immigrants. American Sociological Review, 61(2), 219-230. https://doi.org/10.2307/2096332

Pradel-Miquel, M. (2016). Crisis, (re-)informalization processes and protest: The case of Barcelona. Current Sociology, 65(2), 1-13.

Rifkin, J. (1996). El fin del trabajo. Nuevas tecnologías contra puestos de trabajo: El nacimiento de una nueva era. Barcelona: Paidós.

Samson, M. (2009). Rechazando a ser excluidos: la organización de los recicladores en el mundo. Cambridge: WIEGO.

Sariento, H., Tilly, C., de la Garza Toledo, E., \& Gayosso Ramírez, J.L. (2016). The unexpected power of informal workers in the pulblic square: A comparision of mexican and US organizing models. International Labor and Working-Class History, 89, 131-152. https://doi.org/10.1017/S0147547915000368

Sassen, S. (1988). New York City's Informal Economy. Volume IV. 1988-89 - Conference on Comparative Ethnicity: The Conference Papers, June 1988. Los Angeles: University of California.

Scheinberg, A. (2012). Informal Sector Integration and High Performance Recycling: Evidence from 20 Cities. Cambridge: WIEGO.

Scheinberg, A., Nesic, J., Savain, R., Luppi, P., Sinnott, P., Petean, F., et al.. (2016). From collision to collaboration - Integrating informal recyclers and re-use operators in Europe: A review. Waste Management and Research, 34(9), 820-839. https://doi.org/10.1177/0734242X16657608

Schneider, F. (2018). Size and development of the shadow economy of 31 European and 5 other OECD countries from 2003 to 2013: A further decline. Retrieved from: http://www.econ.jku.at/members/Schneider/

Shapland, J., \& Heyes, J. (2017). How close are formal and informal work?. International Journal of Sociology and Social Policy, 37(7/8), 374-386. https://doi.org/10.1108/IJSSP-06-2016-0071

Síndic de Greuges de Catalunya (2014). Informe al Parlamento 2013. Barcelona: Síndic de Greuges.

Siqueira, C.E. (2016). Does Informal Employment Exist in the United States and Other Developed Countries?. NEW SOLUTIONS: A Journal of Environmental and Occupational Health Policy, 26(2), 337-339. https://doi.org/10.1177/1048291116650974

Stovel, K., \& Shaw, L. (2012). Brokerage. The Annual Review of Sociology, 38, 139-158. https://doi.org/10.1146/annurev-soc-081309-150054

Subirats, J. (2015). Todo se mueve. Acción colectiva, acción conectiva. Movimientos, partidos e instituciones. Revista Española de Sociología, 24, 123-131.

UGT (2015). Trabajar igual, cobrar igual. UGT.

Voiculescu, C. (2014). Voyagers of the smooth space. Navigating emotional landscapes: Roma street vendors in Scotland. Emotion, Space and Society, 13, 24-31. https://doi.org/10.1016/j.emospa.2014.05.003

Wallerstein, I. (1988). El capitalismo histórico. Madrid: Siglo XXI Editores.

Wallerstein, I. (2013). Structural crisis, or why capitalist may no longer find capitalism rewarding. En I. Wallerstein, C. Randall, M. Michael, G. Derlugian, \& C. Calhoun, Does capitalisn have a future? (pp. 9-37). New York: Oxford University Press.

Williams, C.C. (2013). Tackling Europe's informal economy: A critical evaluation of the neo-liberal de-regulatory perspective. Journal of Contemporary European Research, 9(3), 261-279. 
Wittmer, J., \& Parizeau, K. (2018). Informal Recyclers' Health Inequities in Vancouver, BC. NEW SOLUTIONS:

A Journal of Environmental and Occupational Health Policy, 28(2), 1-23. https://doi.org/10.1177/1048291118777845

Intangible Capital, 2018 (www.intangiblecapital.org)

\section{(c) (i) (5)}

Article's contents are provided on an Attribution-Non Commercial 4.0 Creative commons International License. Readers are allowed to copy, distribute and communicate article's contents, provided the author's and Intangible Capital's names are included. It must not be used for commercial purposes. To see the complete license contents, please visit https://creativecommons.org/licenses/by-nc/4.0/. 